doi:

\title{
Speciális Olimpia mozgalom Kölyök Sportoló programjának állapotfelmérö-eszköze a gyakorlatban
}

\author{
Pázmány Viktória ${ }^{1}$, Lentner Nóra ${ }^{2}$ \\ ${ }^{1}$ tanársegéd, Debreceni Egyetem Egészségügyi Kar Védőnői Módszertani és Népegészségtani Tanszék, Nyíregyhá- \\ za Sóstói út 2-4. \\ ${ }^{2}$ gyógypedagógus, Csalogány Óvoda, Általános Iskola, Készségfejlesztő Speciális Szakiskola és EGYMI, Budapest \\ San Marco u. 48-50.
}

\begin{tabular}{|c|c|}
\hline INFO & ABSTRACT \\
\hline $\begin{array}{l}\text { Pázmány Viktória } \\
\text { pazmany.viktoria@foh.unideb. } \\
\text { hu }\end{array}$ & \multirow{2}{*}{$\begin{array}{l}\text { Abstract. The study provides a snapshot on the adaptation } \\
\text { process of Special Olympics Young Athletes global motor } \\
\text { assessment tool in Hungary. The research was conducted } \\
\text { with the involvement of the experts leading groups of } \\
\text { Young Athletes in Hungary. Its aim is to have the special } \\
\text { educators try and comment on the Hungarian version of } \\
\text { Young Athletes Motor Skills Assessment Check List, as- } \\
\text { sisting with its establishment in the Hungarian praxis. }\end{array}$} \\
\hline $\begin{array}{l}\text { Keywords: } \\
\text { intellecitual disability } \\
\text { sport } \\
\text { Special Olympics } \\
\text { Young Athletes }\end{array}$ & \\
\hline $\begin{array}{l}\text { Kulcsszavak: } \\
\text { értelmi fogyatékos } \\
\text { sport } \\
\text { Speciális Olimpia } \\
\text { Kölyök Sportoló Prog- } \\
\text { ram }\end{array}$ & $\begin{array}{l}\text { Absztrakt: A tanulmány a Speciális Olimpia mozgalom } \\
\text { Kölyöksportoló Programjának nemzetközi felmérő eszkö- } \\
\text { zének magyarországi adaptációs folyamatáról ad pillanat- } \\
\text { képet. A vizsgálat a Magyarországon müködő Kölyök } \\
\text { Sportoló csoportokat vezető szakemberek bevonásával jött } \\
\text { létre abból a célból, hogy az angol nyelvü Young Athletes } \\
\text { Motor Skills Assessment Check List magyarra fordítását } \\
\text { követően azt kipróbálva a gyógypedagógusok véleményez- } \\
\text { zék a felmérőlapot és ezzel segítsék annak a magyar gya- } \\
\text { korlatban való meghonosítását. }\end{array}$ \\
\hline
\end{tabular}

\section{Bevezetés}

A Magyar Speciális Olimpia Szövetség a nemzetközi Speciális Olimpia mozgalom tagjaként 30 éve szervezi értelmi fogyatékos gyermekek, fiatalok és felnőttek sport- és szabadidős tevékenységét. A mozgalom egész éven át tartó, folyamatos edzésekkel, versenylehetőségekkel és rendezvényekkel színesíti a fogyatékos személyek és családjaik életét. Lehetőséget nyújt a verseny- és élsport által a legjobbaknak a kiteljesedésre, de állapottól, képességektől függetlenül minden értelmi fogyatékos személyt segít a 
lehető legteljesebb fejlödésben, az egészséges életmódban, a közösségi élmények megszerzésében. A magyar Szövetség 2015-ben honosította meg a nemzetközi gyakorlatból a Young Athletes, azaz a Kölyök Sportoló Programot, melynek célja a legfiatalabb korosztály és családjaik megismertetése a Speciális Olimpia mozgalommal, és a leendő sportolók, az utánpótlás nevelés mellett a családok számára egy, az addigitól eltérő jövőkép kínálása a fogyatékos gyermekkel közösen. A hazánkban 4 éve müködő program elsősorban korai fejlesztő központokban és óvodákban zajlik csoportos, illetve kiscsoportos mozgásfejlesztés keretében, valamint egy csoportnak egy befogadó sportegyesület ad otthont. Egyelöre két angol és egy magyar nyelvü kiadvány, nemzetközi konferenciákon kapott anyagok, továbbá a Magyar Speciális Olimpia elnöksége és szakág-vezetői segítik munkát. A Kölyök Sportoló program elsődleges célja az utánpótlás felkészítése a sportéletre, iránymutató a családok számára a Speciális Olimpia, és a versenyzés felé. (Young Athletes, 2016)

Munkánk célja a Young Athletes Motor Skills Assessment Check list magyarországi meghonosítása. A tanulmány ennek a folyamatnak egy fontos pillanatképét mutatja be. Általában a gyógypedagógiai tevékenységben, így a mozgásfejlesztésben is a kezdeti állapot felmérése, a diagnosztika és a folyamatos nyomonkövetés hangsúlyos feladat. A Kölyök Sportoló Program - bár szigorúan véve nem a gyógypedagógiai fejlesztés fogalomkörébe tartozik, hiszen föleg a nemzetközi gyakorlatban nem feltétlen intézményes rendszerben, inkább szabadidős tevékenységként jelenik meg a családok életében - a céljait tekintve és a magyar gyakorlat alapján elválaszthatatlan a gyógypedagógiai munkától, ahol a Kölyök Sportoló Program gyógypedagógusok által vezetett foglalkozás. Mivel intézményenként, és gyógypedagógusonként eltérő a felmérés módja, rendszeressége és eszköze is, valamint a hazai gyakorlatban alkalmazott felmérő eszközök nem kifejezetten illeszkednek a mozgásfejlesztés sportszemléletü megközelítéséhez, az elmúlt évek során szerzett tapasztalatokra építve döntöttünk úgy, hogy a nemzetközi Szövetség által létrehozott eszközt a magyar gyakorlatba is átültetjük. Vizsgálatunk az angol nyelvü Young Athletes Motor Skills Assessment Check list magyar nyelvü adaptálásának céljából az eszközt kipróbáló edzők tapasztalataira irányult. A szakemberek gyakorlatból eredő észrevételei a mérőeszközzel kapcsolatban iránymutatók a mérőeszköz magyar nyelvü gyakorlatba való átültetésében.

\section{A Speciális Olimpia és a Kölyök Sportoló program}

A Speciális Olimpia versenyzői, így az utánpótlás programban részt vevők is az értelmi fogyatékos személyek csoportjába tartoznak (Regényi-Virányi-Jády, 2017). A hazai programban tanulásban és értelmileg akadályozott tanulók, és még pontos besorolást nem kapott óvodások vannak jelen. A nemzetközi terminusok szerint a Kölyök Sportoló program egészen kiskortól, 2-3 éves kortól 7- 8 éves korig foglalkozik értelmi fogyatékos gyermekekkel és családjaikkal (Young Athletes, 2016). A hazai gyakorlatban azonban az intézményes jelleg miatt óvodáskorú és alsó tagozatos gyermekek vesznek részt a foglalkozásokon 10 éves korig. Az eredetileg, angol nyelven Young Athletes nevü projekt, értelmileg akadályozott és ép gyermekek 
(„children with and without intellectual disabilities”) számára készített program. Fő célja, a mozgás, a különböző sportágak megismertetése és megszerettetése a Kölyök Sportolókkal. Szabadidős tevékenységet kínál a gyermekeknek, pedagógusaiknak, családjaiknak és az önkénteseknek, valamint irányt mutat a Speciális Olimpia közössége felé a kisgyermekes szülöknek. A Kölyök Sportoló Program legkiemelkedőbb célja, hogy az értelmileg akadályozott kisgyermekek és családjaik is megismerkedhessenek a Speciális Olimpia világával, már egész kis korban is sportszemléletü mozgásfejlesztésen vegyenek részt. A program öt fö területen vár változást a mozgásos foglalkozások eredményeként:

1. Motoros képességek és készségek

2. Szociális, emocionális és tanulási képességek, készségek

3. Sportkészségek

4. A gyermek állapotának elfogadása

5. A gyermekkel szembeni elvárások

A magyar gyakorlatba 2015-ben került be a program a Magyar Speciális Olimpia elnökségének javaslatára. Először egy csoporttal, a budapesti Csalogány Intézményben indultak meg a foglalkozások, majd a bemutatóknak, előadásoknak, népszerüsítő videóknak köszönhetően évente 1-2 óvoda, iskola csatlakozott a programhoz. A 2019/2020-as tanévben 6 speciális intézményben és egy befogadó sportegyesületben zajlanak rendszeresen az edzések, rendezvényeinken pedig többségi gyermekek egyre növekvő létszámmal, közel 1/3-os arányban szerepelnek. Jelenleg 11 gyógypedagógus, 3 gyógypedagógiai asszisztens foglalkozik közel 50 gyermekkel heti rendszerességgel.

Ezeken a foglalkozásokon - épp úgy, mint bármely más kiscsoportos mozgásfejlesztésen - nem beszélhetünk tisztán mozgásos készségek fejlesztésröl, hiszen a kognitív képességekre, mint például a figyelem, a szociális készségekre, kommunikációs készségekre egyaránt szükség van. A gyermekek fejlődnek alapmozgásaikban, de gyakorolják a kivárást, türelmet, egymásnak szurkolást, valamint különböző kommunikációs eszközöket használnak. A program alapelvét alátámasztja számos szakirodalmi meghatározás, melyek szerint, a mozgáson keresztül az összes készséget hatékonyan fejleszthetjük, a mozgás megfelelő motivációs bázist nyújt az egyéb területek megalapozására.

A sport számos képesség, készség fejlesztésére alkalmas, számos cél eszközéül szolgáló tevékenység. Értelmi fogyatékos személyeknél lehet a fejlesztő munka eszköze, munka helyett mindennapi motiváció és cél, szabadidős tevékenység, mely által a sportolók kitartást gyakorolnak, szociális kapcsolataikat erősítik, fejlődik az önértékelésük, önbizalmuk és az egyik legfontosabb, hogy sikerélményt szereznek. Emellett az értelmi fogyatékos személyek sportja nem csak az adott személyre, hanem környezetére is hatással van, az eredmények elősegíthetik a társadalmi elöítéletek leküzdését, a fogyatékos személyek integrációját, elfogadását és az esélyegyenlőség elősegítését is (Gruiz, 2003).

Értelmi fogyatékos gyermekek és felnőttek esetén ugyanúgy „kedvezően befolyásolja az aktivációs és teljesítménynívót" a tudatosan felépített és megtervezett testnevelés óra, vagy edzés. (Nádori, 1993, p.23.) Rendszeres sportélet esetén az érintett személyeknél a kognitív képességek, mint az ,intelligencia, szókincs, megfi- 
gyelőképesség”, valamint a szociális készségek terén figyelhető meg javuló teljesítmény. Az „egyén fizikai-pszichikai teljesítőképessége, teljesítménye”, a „terhelésszabályozás, mint a keringés-légzés és energiafelhasználás" és természetesen a motorikus teljesítmény is javul (Nádori, 1993).

Értelmi fogyatékos személyek esetén a mozgást felhasználva indíthatók be motivációs folyamatok. „Az értelmi fogyatékos gyermekek a tevékenységen, illetve a mozgáson keresztül könnyebben megközelíthetök, mert a motorium területén- a kognitív szférához képest- bizonyíthatóan erősebb képesség-készségkészletük van. A motorikus folyamatok az értelmi fogyatékos gyermeket lényegesen jobban motiválják, kedvezőbb élményt nyújtanak, mint a tisztán kognitív-szociális-emocioális folyamatok,, (Nádori, 1993, p. 24.). A fenti elméletre épülnek azok az alátámasztások, melyek az értelmi fogyatékos személyek sportolásának fontosságát, létjogosultságát igazolják. Nádori László 1993-as tanulmányában a következőképpen érvel: „A sport a természetes gyermeki igénynek- a mozgás, funkcionalitás és aktivitás révén közvetlenül megfelel” (Nádori, 1993, p. 24.). Eltérően más területektől a sport Nádori megfogalmazásában „képesség-semleges” természetü, összetett, komplex képességstruktúrát igényel, nem pedig ,szigorúan körülírt képesség-készségszintet, az értelmi fogyatékosság meghatározott szintjein” (Nádori, 1993, p. 24.). Az egyik legfontosabb pozitív hozadéka a rendszeres sport és versenyéletnek a siker, elismerés, győzelem, vagy akár kudarc, vereség megélésre, ezen élmények hatással vannak az egyénre, önmaga megismerésére. Kiemelendő, hogy a sikerek, és kudarcok megtapasztalása befolyással bír a személy személyiségfejlődésére, az önállóság, öntudat, önismeret egyre nagyobb mértéke hozzájárul a saját képességeibe vetett bizalmához (Nádori, 1993).

Értelmi fogyatékos személyek esetén akár mozgásfejlesztésről, akár konkrét sportfoglalkozásról beszélünk, alapelvek közé soroljuk a tervszerüséget, téri és tárgyi rendezettséget, figyelem felkeltését, gyakorlatok ismétlését és begyakorlását, változatos gyakorlatok tervezését, valamint különös hangsúllyal a megfelelő motiváció kialakítását, kudarcélmények elkerülését, valamint azok esetleges feldolgozását (Horváth, Barthel, 2003 p.181.).

A nemzetközi szövetség, valamint a program módszertani ajánlásai leginkább szemléletet, eszmét határoznak meg. Játékgyüjtemény, ötlettár segíti a foglalkozást vezetőket a tervezésben, de ezek csupán a szemléletet adják, ajánlást kínálnak a foglalkozások felépítéséhez. Ezek az összegyüjtött mozgásos játékok a mozgásnevelés, testnevelés módszertanával.

\section{A Young Athletes - Motor Skills ssessment/Check List}

A módszertani füzetek számos eszközt, azok képekkel illusztrált változatos használati javaslatát mutatják be. Ezen eszközök egyike a kutatás témája, a Young Athletes Motor Skills Assessment Check list. A nemzetközi szövetség által készített, kifejezetten a Kölyök Sportoló programban részt vevő ép és értelmi fogyatékos gyermekek mozgásos képességeinek felmérésére alkalmas eszközzel lehetősége van a szak- 
embereknek a program megkezdése előtt, majd adott időközönként megállapítani a gyermekek mozgásállapotát, így a fejlődés mérhető és követhető lesz. A felmérő lap hazai bevezetésének jelenlegi helyzetét követjük nyomon a tanulmányban. Jelenleg az adaptáció folyamatában a szük körben terjesztett felmérő lap szakemberek általi véleményezése, lektorálása van folyamatban. A Magyar Speciális Olimpia Szövetség tervezi, hogy a végleges változatot honlapján hozzáférhetővé teszi minden érdeklődő számára. A sport szemléletü mozgásfejlesztéssel foglalkozó Kölyök Sportoló programban részt vevő csoportok számára az útmutató az alábbi nagymozgások gyakorlását ajánlja:

- Alapozó készségek

- Járás és futás

- Egyensúlyérzékelés és ugrás

- Labda fogása és elkapása

- Dobás

- Ütés

- Rúgás

- Haladó sportkészségek

A labdagyakorlatok alapjainak elsajátítása során egyik cél a Kölyök Sportoló programban, hogy később az adott sportág edzésein már készségszinten tudja a gyermek. Ezen gyakorlatok szolgálnak a többek között a bowling, a tenisz, a tollaslabda, a kosárlabda, labdarúgás, floorball, kézilabda, röplabda alapjául. A haladó sportkészségek a Kölyök Sportolók esetén a sportágakkal való megismerkedés, sportspecifikus készségek elsajátítása, valamint ezek sportkörnyezetben való alkalmazásának gyakorlása a cél. A gyermekek már egészen óvodás korban sport-specifikus mozgásokat sajátítanak el, valamint sportversenyeken vesznek részt.

Összehasonlítva a gyógypedagógiában és a Kölyök Sportoló programban kijelölt fejlesztési területeket és célokat megállapítható, hogy csupán célját tekintve tér el egymástól a kettő: míg az egyik a kognitív, szociális és egyéb készségeket kívánja kiegészíteni, addig a másik típusú foglalkozás ezen területek mellett a sportéletre való felkészítéssel foglalkozik. Ugyanazon gyermekek ugyanazon mozgásos területei fejlesztésében megjelenő különbségeket a fókuszeltolódás eredményezi, a két irányzat tehát nem ellentétes egymással, csupán a fókusza eltérö.

\section{A vizsgálat}

Munkánk során elsősorban a programban részt vevő gyógypedagógus végzettségü edzőknek a tapasztalatait, véleményét vizsgáltuk meg a Kölyök Sportoló Felmérő lappal kapcsolatban, összehasonlítva azt a komplex vagy kizárólag mozgásállapot vizsgálatra alkalmas felmérő eszközökkel. Fontos kérdése volt a vizsgálatnak, hogy a sport szemléletü, kifejezetten a Kölyök Sportoló programban részt vevő gyermekekre készített eszköz mely elemeiben egyezik gyógypedagógiai felmérő eszközzel, illetve milyen mértékben specifikus, eltérő attól? 
A felmérésben részt vevők tapasztalatait az írásbeli kikérdezés indirekt módszerén keresztül ismertük meg. Személyes interjúra a földrajzi távolságok és a válaszadók elfoglaltsága miatt nem volt lehetőség. A beérkezett információkat a tartalomelemzés módszerével elemeztük.

Első kérdéscsoportban a részt vevő gyógypedagógusokat a végzettségükről, munkájukról, a Speciális Olimpia mozgalommal illetve a Kölyök Sportoló programmal való kapcsolatukról kérdeztük. Majd nyílt kérdésekkel térképeztük fel, hogy milyen előzetes ismereteik vannak értelmileg akadályozott gyermekek mozgásállapotára vonatkozó felmérésekröl, milyen eszközöket használnak a gyakorlatban. Ezen kérdések egy része rövid válaszokat, míg másik részük tanult ismeretek közlését igénylö kérdés volt. Ezt követően kértük öket, hogy fejtsék ki a Kölyök Sportoló program keretei között bevezetésre kerülő felmérö lappal kapcsolatban véleményüket. Kiváncsiak voltunk annak alkalmazhatóságára, valamint, hogy a szakemberek munkáját mennyiben segítheti az az állapotfelmérésben illetve a fejlesztésben. Kérdéseinkkel kitértünk a mérőeszköz előnyeire és hiányosságaira egyaránt.

Minden, a kutatásban részt vevő személy legalább egy gyermekkel elvégezte Kölyök Sportoló Felmérő lap feladatait, majd ezt követően válaszolt a kérdésre. A 17 kérdésből álló dokumentumot 11 gyógypedagógus illetve gyógypedagógiai asszisztens kapta meg, akik mindannyian visszaküldték válaszaikat.

\section{Vizsgálat eredményei}

A Kölyök Sportoló programban bevezetésre kerülő felmérő lappal kapcsolatos kérdésekre 11 fő válaszolt, akik közül 1 fö kivételével - aki gyógypedagógiai asszisztens - minden válaszadó gyógypedagógus végzettségü. Előzetesen különbséget vártunk a régebb óta a szakmában dolgozó gyógypedagógusok és a pályakezdők megfogalmazásában, felmérő eszközökben való jártasságban, de a válaszok leginkább a munkahelyi sajátosságokat tükrözték - például a korai fejlesztés területén dolgozók korai életkorban használt felmérő eszközöket soroltak. A bevezető kérdésekben nem szerepelt a munkahely, valamint a korosztály, akikkel foglalkoznak, így e szempont alapján nem hasonlíthattuk össze a válaszokat.

A kutatásban részt vevők többnyire fiatalok, 4-5 éve foglalkoznak értelmi fogyatékos gyermekekkel, 2 fö 14-15 éve van a pályán. A Kölyök Sportoló programhoz a kezdetektől 2 fö csatlakozott, a többiek 1-3 éve foglalkoznak az óvodás és kisiskolás korú értelmi fogyatékos gyermekek mozgásfejlesztésével, sportéletre történő felkészítésével a Magyar Speciális Olimpia Szövetség keretein belül. Végzettséget tekintve a gyógypedagógusok közül 2 fő bölcsészképzésben, 1 fö óvodapedagógus képzésben, 3 fö mesterképzésben is részt vett, egy fö pedagógus szakvizsgát tett. Emellett a kitöltők közül 2 fö masszőrként tanult, 2 fő Kölyökatlétika képzést, 1 fö szivacskézilabda képzést végzett, valamint számos mozgásfejlesztéssel kapcsolatos tanfolyamon bővítették szaktudásukat. A válaszokat tekintve - kiemelve itt az ismert és használt vizsgáló eljárásokra, és a felmérő lap hiányosságaira vonatkozó kérdést - nem mutatkozott különbség azon szakemberek véleményében, akik sportspecifikus tanfolyamokon, képzéseken vettek részt. 
A Kölyök Sportoló felmérő lappal kapcsolatos véleményükön kívül fontosnak tartottuk felmérni, hogy a válaszadók milyen felmérö eszközöket ismernek, és használnak. Célunk volt, hogy kapcsolatot fedezzünk fel, a válaszadók által ismert és használt vizsgáló eljárások és a Kölyök Sportoló felmérő lappal kapcsolatos tapasztalataik között, de a válaszok inkább arra engednek következtetni, hogy mely területen, milyen életkorú gyermekekkel foglalkoznak munkájuk során (pl. korai fejlesztés területén, mozgásneveléssel). Arra a kérdésre, hogy milyen, értelmileg akadályozott gyermekek mozgásos képességeinek felmérésére alkalmas eszközöket ismernek, legtöbben saját készítésü, vagy intézményi szinten használt vizsgáló eszközt, a Strassmeier fejlődési skálát, a P.A.C. egyes elemeit, speciális, terápiákhoz (P1. Vojta, Katona vagy Ayres terápiák) tartozó vizsgáló eljárások felméréseit, valamint a Lakatos Katalin nevéhez füződő Állapot és mozgásvizsgálatot sorolták fel. 2-2 fó említette a Kiphard-féle szenzomotoros és pszichoszociális fejlődési táblázatot és a Kulcsárné-féle komplex fejlesztés felmérését. Csupán 1-1 kérdéssorban jelent meg a válaszok között a Lincoln-Oseretzky fejlődési skála, a Netfit, a Movement ABC, a HKI és a Portage. Kiemelendö, hogy a Netfitet az a szakember jelölte meg, akinek nincsen sportág-specifikus vagy testnevelöi végzettsége, a Movement ABC-t és a Portage-t pedig azok a gyógypedagógusok sorolták fel, akik részt vettek valamilyen mesterképzésben. 1 fö a felmérő eszközöknél vizsgáló eljárások helyett tárgyi eszközöket - mint a zsámoly, gerenda, szivacs - sorolt fel.

\begin{tabular}{|c|c|c|c|c|c|c|c|c|c|c|c|c|}
\hline & \multicolumn{10}{|c|}{ Felmérö eszközök } \\
\hline Edzö & $\mathrm{A}$ & $\mathrm{B}$ & $\mathrm{C}$ & $\mathrm{D}$ & $\mathrm{E}$ & $\mathrm{F}$ & $\mathrm{G}$ & $\mathrm{H}$ & $\mathrm{I}$ & $\mathrm{J}$ & $\mathrm{K}$ & $\mathrm{L}$ \\
\hline 1 & $\mathrm{X}$ & & & $\mathrm{X}$ & $\mathrm{X}$ & & & & & & & \\
\hline 2 & $\mathrm{X}$ & & & $\mathrm{X}$ & $\mathrm{X}$ & & & & & & & \\
\hline 3 & & $\mathrm{X}$ & $\mathrm{X}$ & & & $\mathrm{X}$ & & & & & & \\
\hline 4 & & $\mathrm{X}$ & & & & & & & & & & \\
\hline 5 & $\mathrm{X}$ & & $\mathrm{X}$ & & $\mathrm{X}$ & & & & & $\mathrm{X}$ & & \\
\hline 6 & & & & $\mathrm{X}$ & & & $\mathrm{X}$ & & & & $\mathrm{X}$ & \\
\hline 7 & $\mathrm{X}$ & $\mathrm{X}$ & & & & $\mathrm{X}$ & & & & & & \\
\hline 8 & & $\mathrm{X}$ & $\mathrm{X}$ & & & & & & & & & \\
\hline 9 & & & $\mathrm{X}$ & $\mathrm{X}$ & & & & & $\mathrm{X}$ & & & \\
\hline 10 & $\mathrm{X}$ & & & & & & $\mathrm{X}$ & $\mathrm{X}$ & & & & $\mathrm{X}$ \\
\hline 11 & $\mathrm{X}$ & & & & $\mathrm{X}$ & & & & & & & \\
\hline & 6 & 4 & 4 & 4 & 4 & 2 & 2 & 1 & 1 & 1 & 1 & 1 \\
\hline
\end{tabular}

1. táblázat: Felmérő eszközök használata a Kölyök Sportoló programban résztvevő edzők körében 
Felmérő eszközök:
A. Saját készítésü felmérés
B. P.A.C.
C. Strassmeier
D. Speciális, terápiákoz tartozó vizsgáló eljárások (Vojta, Katona, Ayres)
E. Állapot és mozgásvizsgálat (Lakatos Katalin)
F. Kliphard-féle szenzomotoros és pszichoszociális fejlődési táblázat
G. Kulcsárné-féle komplex fejlesztés felmérése
H. Lincoln Oseretzky skála
I. Netfit
J. Movement ABC
K. HKI
L. Portage

Feltételeztük, hogy azok a szakemberek, akik az általuk eddig használt felmérő eszközökkel elégedetlenek, nyitottabbak lesznek a Kölyök Sportoló felmérő lap felé, de minden válaszadó megfelelőnek tartja az adott célra az általa használt felmérő eljárást, és előremutatóan nyilatkozott az új felmérő eszközről is.

Kérdéseink fókuszában a Kölyök Sportoló felmérő lappal kapcsolatos első benyomások megismerése állt, célunk volt felmérni, hogy hasznosnak, használhatónak tartják-e a hazai kollégák az eszközt, milyen hiányosságait, előnyeit tapasztalják. A Kölyök Sportoló programban hazai bevezetésre kerülö felmérö lapot minden válaszadó hasznosnak tartja a gyermekek képességeinek megállapítására:

„Kiindulási pontként szolgálhat a sportfoglalkozások megtervezésében.”

"Átfogó képet ad a gyermekek képességeiről."

„Globális képet ad a gyermekek mozgásos képességeiről.”

„A megfelelő mozgásformák felméréséhez sok segítséget adnak."

„Átfogó képet ad a gyermekek aktuális mozgásállapotáról. Megmutatja, mely területek müködnek megfelelően, vagy kiemelkedően és mely terület fejlesztendő hangsúlyosabban."

„Különböző helyzeteket és teljesítményeket mérek fel a lap segítségével, így jobban fel tudom mérni a gyermekek fejlödési szintjét egymáshoz viszonyítva is, és korábbi önmagukhoz képest is."

Egyes válaszokban benne rejlik a fejlesztés iránti igény is:

„Segítséget fog nyújtani, kisebb módosítással, esetleg bővítéssel. Jó az alapkoncepnció, a feladatok könnyebbek, jól érthetőek, sokszínủek, az alapkészségeket átveszik."

„Az alapvető területek hiányosságira rávilágít, de lehetne részletesebben lebontva.”

„Támogatom és örülök neki, hogy lett egy saját felmérő eszközünk. A gyerekekkel felvett felmérés alapján új dolgot (hiányt vagy fejlődést) nem tudtam meg a gyermekekről. Új gyermek mozgásos képességeinek megismerésére viszont nagyon jól alkalmazható."

A fejlesztő munka tervezésében a Kölyök Sportoló programban résztvevők a felmérést új gyermek érkezése esetén, a hiányosságok megállapítására, fejlesztési célok és a következő lépcsőfokok kijelölésére tartják leginkább alkalmasnak. Úgy vélik, segítséget nyújt azon területek, feladatok megállapítására, amelyek a gyermekek önbizalmát, motivációját növelik. 
Az eszköz gyengeségeként a pontos megfogalmazások, feladatleírások, szakkifejezések hiányát emelték ki a válaszadók. A gyakorlatok közül a testsúly, testmagasság lejegyzését, lépcsőzés, hajlékonyság vizsgálatát, részletesebb egyensúly, koordináció felmérést, valamint vízben történő vizsgálatot is javasoltak. Nehézséget okozott továbbá a felvétel során, hogy az eszköz nem ad pontos, egyértelmü utasításokat (pl. guruló labdába rúgás) sem a fordításban, sem az eredeti angol megfogalmazásban. Ugrások vizsgálatakor az egyik válaszadó nehezményezte, hogy a magasugrás mérésekor nincs segédeszköz, vagy részletes leírás, ami segíteni a felmérést végző munkáját a mérésben, valamint többen is jelezték, hogy az egy lábon ugrás vizsgálatakor célszerü lenne jobb és bal lábbal is elvégeztetni a gyakorlatot, a jobb eredményt rögzíteni és megjegyzésben jelölni a használt oldalt.

Egy sarkalatos pontja a felmérő lapnak a járógyakorlatok vizsgálata. A „Járás és tárgy szállítása" témában a felmérő lap nem határoz meg konkrét feladatot, így a felmérést végző gyógypedagógusok a saját kreativitásukra, ötleteikre hagyatkoztak. Egyes szakemberek a felhasználható eszközökből gazdálkodva a gyermekeknek azt a feladatot adták, hogy teniszlabdát nyújtott ujjaikon, felfelé néző, tetszőleges oldalú tenyerükön vigyenek, míg mások babzsák, Wesco tégla „szállításával” mérték fel ezt a területet. A tapasztalatok alapján átírásra került a feladat szövege, és meghatározva egy labda két kézben tartásával vizsgáljuk ezt a pontot.

\begin{tabular}{|c|c|c|c|c|c|}
\hline Edző & $\begin{array}{c}\text { szakmailag } \\
\text { megfelelő } \\
\text { nyelvezet }\end{array}$ & $\begin{array}{c}\text { utasítások precíz } \\
\text { megfogalmazása }\end{array}$ & $\begin{array}{c}\text { további } \\
\text { vizsgálandó } \\
\text { területek }\end{array}$ & $\begin{array}{c}\text { segédeszközök } \\
\text { hiánya }\end{array}$ & $\begin{array}{c}\text { jobb és bal } \\
\text { oldal / domi- } \\
\text { nancia vizsgá- } \\
\text { lata }\end{array}$ \\
\hline 1 & $\mathrm{X}$ & $\mathrm{X}$ & & $\mathrm{X}$ & \\
\hline 2 & & $\mathrm{X}$ & $\mathrm{X}$ & & $\mathrm{X}$ \\
\hline 3 & $\mathrm{X}$ & $\mathrm{X}$ & $\mathrm{X}$ & $\mathrm{X}$ & \\
\hline 4 & & $\mathrm{X}$ & $\mathrm{X}$ & & $\mathrm{X}$ \\
\hline 5 & & $\mathrm{X}$ & & & $\mathrm{X}$ \\
\hline 6 & & $\mathrm{X}$ & $\mathrm{X}$ & & $\mathrm{X}$ \\
\hline 7 & & $\mathrm{X}$ & $\mathrm{X}$ & $\mathrm{X}$ & \\
\hline 8 & & $\mathrm{X}$ & $\mathrm{X}$ & & $\mathrm{X}$ \\
\hline 9 & & & & & \\
\hline 10 & & & & & \\
\hline 11 & & & & & \\
\hline
\end{tabular}

2. táblázat: Felmérő lap hiányosságai, gyengeségei

A beérkező válaszok közül a felmérő lap előnyei között kiemelték a szakemberek, hogy a vizsgálat könnyen, egyszerủen kivitelezhetö, kevés eszközt igényel és rövid idő alatt felvehető. Emellett az eszköz jó hasznosíthatósága mellett szól az is, hogy a könnyen végezhető gyakorlatok miatt sok gyermek esetében alkalmas az eszköz a vizsgálatra, akár a súlyosabb sérüléssel élőkkel is elvégezhető. Átfogó szemlélete miatt a fejlödés több területére is kiterjed a vizsgálat, ezzel egyértelmübb képet adva a programban részt vevő gyermekek fejlettségi szintjéről. A feladatok játékos mivolta pedig a figyelem fenntartását, a motivációt segíti. 


\begin{tabular}{|c|c|c|c|c|c|c|}
\hline Edzö & $\begin{array}{c}\text { egyszerü } \\
\text { vizsgálat }\end{array}$ & $\begin{array}{c}\text { kis eszköz } \\
\text { igényü }\end{array}$ & $\begin{array}{c}\text { kis időtar- } \\
\text { talmú }\end{array}$ & $\begin{array}{c}\text { könnyü gya- } \\
\text { korlatok }\end{array}$ & $\begin{array}{c}\text { átfogó } \\
\text { szemlélet }\end{array}$ & játékos \\
\hline 1 & & $\mathrm{X}$ & & $\mathrm{X}$ & $\mathrm{X}$ & \\
\hline 2 & $\mathrm{X}$ & & $\mathrm{X}$ & $\mathrm{X}$ & $\mathrm{X}$ & \\
\hline 3 & & & $\mathrm{X}$ & & & $\mathrm{X}$ \\
\hline 4 & $\mathrm{X}$ & $\mathrm{X}$ & & & $\mathrm{X}$ & $\mathrm{X}$ \\
\hline 5 & $\mathrm{X}$ & & $\mathrm{X}$ & & & \\
\hline 6 & & & & $\mathrm{X}$ & $\mathrm{X}$ & $\mathrm{X}$ \\
\hline 7 & $\mathrm{X}$ & $\mathrm{X}$ & & & & \\
\hline 8 & & $\mathrm{X}$ & $\mathrm{X}$ & & & $\mathrm{X}$ \\
\hline 9 & & & $\mathrm{X}$ & $\mathrm{X}$ & & $\mathrm{X}$ \\
\hline 10 & $\mathrm{X}$ & $\mathrm{X}$ & & $\mathrm{X}$ & & \\
\hline 11 & $\mathrm{X}$ & & & & $\mathrm{X}$ & \\
\hline
\end{tabular}

3. táblázat: Felmérő lap erősségei

A felmérés gyermekenként átlagosan 15-30 percet vett igénybe első alkalommal a gyógypedagógusoknak. A felmérés elvégzésekor a válaszadók a következőket tapasztalták:

„A gyermekeknek egy picit unalmas volt, persze egy szép mese keretében izgalmassá lehet tenni nekik."

„A gyermekek élvezték, hogy mérjük őket, viszont célszerü legalább egy plusz kollégával elvégezni."

„Mindegyik gyermek a legjobb teljesítményét adta, és szerintem elég gyorsan megértették a feladatot."

„A gyermekek örömmel végezték a feladatokat. Jelen esetben a felméréseket 2 felnőtt végezte, amely meggyorsította és talán pontosabbá is tette az adatok felvételét."

„Élvezettel végezték a gyerekek, nem volt megterhelő számukra és nem volt unalmas." "Gördülékeny, érthető, kivitelezhető, könnyen felmérhető."

A tapasztalatok egyik kiemelt konzekvenciája, hogy a feladatsor precíz elvégzéséhez és a megfigyelések rögzítéséhez 2 szakember jelenléte szükséges.

A feladatvégzés során a segítségnyújtás mértéke nem meghatározott az eljárás leírásakor, így felmerül a kérdés, hogy nyújthatunk-e a gyermeknek a vizsgálat során a bemutatást követően verbális, vizuális vagy manuális segítséget. Ebben a tekintetben szintén további egyeztetés illetve finomítás szükséges.

A felmérésnél nehézséget okozott, hogy több gyakorlatnál nem volt egyértelmü a feladatleírás, feladatmegfogalmazás, szükség volt többszörös bemutatásra, facilitálásra, problémát okoztak a tér korlátai- a futás és a rúgás vizsgálatakor-, a magasugrás pontos lemérése. Járógyakorlatoknál több gyógypedagógusban felmerült a kérdést, hogy mindkét irányba kell-e végezni a gyakorlatokat, ha nem akkor ki dönti el, hogy melyik irányba történjen a mozgás, valamint, hogy hátrafelé járásnál feladat-e, hogy a vonalon maradjon a gyermek. Továbbá az egyik szakember jelezte, hogy számára a labdás feladatoknál nem egyértelmü az utasítás megfogalmazása, hogy gurításnál, rúgásnál a gyermekhez képest a felmérést végző személy milyen irányban álljon.

A kérdéssor egyik fő kérdése volt az is, hogy a válaszadók a jövőre nézve tervezik- e használni a Kölyök Sportoló felmérő lapot. A kitöltők mindegyike azt 
válaszolta, hogy alkalmazhatónak tartja a felmérő eszközt a gyermekek mozgásos képességeinek, készségeinek nyomon követésére, úgy gondolják, megfelelő és szükséges finomításokat követően használni fogják, de két válaszadó kiemelte, hogy nem önmagában, hanem más gyógypedagógiai felmérő eljárásokkal kiegészítve fogja alkalmazni.

\section{Összegzés}

Munkánk során egy új felmérő eszközt kívántunk megismertetni és véleményeztetni gyakorló szakemberekkel. Úgy véljük, hogy a diagnosztika, a felmérés mellett az edzők, gyógypedagógusok, és a programban részt vevők gyógypedagógiai szemléletének összekapcsolódása a sport- és versenyélettel kiegészíti egymást, és ezáltal lesz komplementer, átfogó és teljes a Kölyök Sportoló program.

A kipróbálást követően a gyógypedagógusok javaslatait figyelembe véve kijavításra került a feladatok leírása, valamint megjegyzésként egyes feladatoknál (pl. tárgy szállítása, guruló labda rúgása) pontosabb feladatleírás szerepel, hiszen célunk, hogy egységes eljárásként minden felvétel azonos legyen, hogy az eredmények öszszehasonlíthatóak legyenek.

Bízunk benne, hogy a Kölyök Sportoló program felmérö lapjának hazai bevezetése sikeres lesz. Azonban a hivatalos közzététel előtt további vizsgálatok, próbák, egyeztetések és finomítások szükségesek.

Ismerve a felmérő lap korlátait, mint hogy ez nem egy standardizált vizsgáló eljárás, önmagában nem alkalmas gyógypedagógiai állapotleírásra, képességek megállapítására, tevékenység tervezésére, az eszköz kizárólag a mozgásos képességekre, készségekre fókuszál. Az átfogó tervezéshez, felméréshez nem elegendő csupán a mozgásos képességprofil jellemzése, de ezt a Check list nem is ígéri. Olyan, kiegészítő eszközt kínál, amely a Kölyök Sportoló program résztvevőinek előzetes, utólagos és összehasonlító felmérésével a szükséges feladatok kijelöléséhez járul hozzá. Mivel a Kölyök Sportoló Program Felmérő lapjának pontjai közvetlenül mérik azokat a képességeket, készségeket, amelyek a Kölyök Sportoló Program tananyagát képezik, a dolgozat címében is szereplö gyakorlatban közvetlenül hasznosítható. Ez a gyakorlat azt mutatja, hogy a hazai „edzők” elégedettek az új vizsgáló eljárással, a kipróbálást követően a válaszadók mindegyike tervezi, hogy munkája során alkalmazni fogja az eszközt.

\section{Felhasznált irodalom}

1. Barthel Betty (2005): A mozgásnevelés sajátosságai és módszertana, In: Dr. Varga Imre (szerk.): Speciális didaktika I.- Az értelmileg akadályozottsággal élő gyermekek tanítása. Szeged. 70-120.

2. Nádori László (1993): Értelmi fogyatékosok testnevelését és sportját vizsgáló kutatások In: dr. Göllesz Viktor (szerk.): Életminőség- fejlesztő speciális mozgalmak a fogyatékosságügyben. Budapest, A Szociális Munka Alapítvány Kiadványai 9. 21-27. 
3. Regényi Enikő, Virányi Anita, Jády György (2017): Tanulásban akadályozott, valamint értelmileg akadályozott személyek testkultúrája In: Benczúr Miklósné (szerk.): Az adaptált testkultúra és sport fogyatékosságspecifikus alapismeretei. Budapest, ELTE-BGGYK. 79-92.

4. Special Olympics Young Athletes (2016)- Activity guide (kézikönyv) https://media.specialolympics.org/resources/community-building/youngathletes/young-athletes-activity-guide/YoungAthletes-Activity-Guide-Print.pdf (letöltve: 2019.03.12)

5. Special Olympics Young Athletes (2017)- Facilitator guide (kézikönyv) https://media.specialolympics.org/resources/community-building/youngathletes/young-athletes-facilitator-guide/YoungAthletes-Facilitator-GuidePrint.pdf (letöltve: 2019.03.12)

6. Special Olympics- Young Athletes Motor Skills Assessment, 2017 https://media.specialolympics.org/resources/community-building/youngathletes/Motor-Skills-Assessment.pdf (letöltve: 2019.02.09) 


\section{Melléklet}

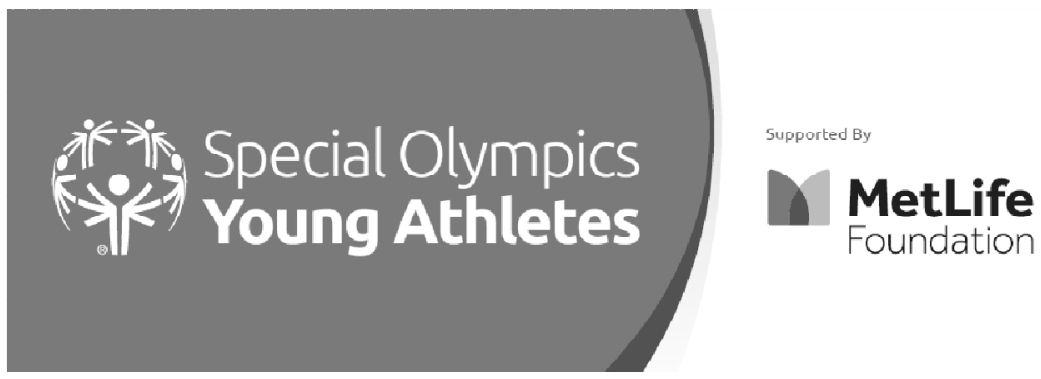

\section{Speciális Olimpiai Kölyök Sportoló Program Felmérö lap}

\section{Bevezetés}

Speciális Olimpiai Kölyök Sportoló Program

A Speciális Olimpia Kölyök Sportoló Programja egy játék- és sportprogram ép és értelmi fogyatékos gyerekek számára, hazánkban 3-tól 10 éves korig. A Kölyök Sportoló Program a mozgásos foglalkozások során megismerteti a gyermekekkel a különbözö sportágakat, olyan mozgásos képességeket, készségeket, sajátítanak el, mint például a futás, rúgás és dobás, amelyek később sportágak alapjául szolgálnak. A Kölyök Sportoló Program közösségi élményt kínál családoknak, tanároknak, gondozóknak, közösen osztozhatunk a mozgás örömében!

A program megvalósításának, és a részvételnek nincsen előfeltétele, minden képességszintü gyerek részt vehet. A gyerekek megtanulnak együtt játszani és a tanuláshoz nélkülözhetetlen kognitív, kommunikációs, szociális képességeik, készségeik fejlődnek mozgás által. Megtanulnak együttmüködni, sorban következni, türelmesen várni és utasításokat végrehajtani. Ezek a készségek segítik a gyerekeket a családi, közösségi és iskolai elfoglaltságaikban.

A Kölyök Sportoló Program játékos módon tanítja a gyerekeket az egészséges életmódra. Fontos egészen kiskorban kialakítani az egészséges szokásokat, melyek megteremthetik a testmozgás, a barátság és a tanulás alapjait a későbbi életkorokra.

A Kölyök Sportoló Program egyszerü eszközökkel könnyen és változatosan végezhető, jó szórakozás mindenki számára. A Kölyök Sportoló Útmutatóját és alapfelszerelését használva, teljesíthető otthon, az iskolában, vagy gyerekközösségben. A Kölyök Sportoló Programban minden gyerek, a családjaik és a közösség tagjai is egy befogadó csapat tagjai lehetnek.

\section{Felmérō lap}

A Kölyök Sportoló Program felmérő lapja azon gyógypedagógusok, edzők, szülők és gondozók számára készült, akik a motoros teljesítmény objektív mérőszámait keresik. A felméréseknek köszönhetően a program megkezdése előtt, illetve a fejlesztési időszak (iskolai modellben tanév) végén mért eredmények összehasonlíthatók, nyomon követhető a gyermekek fejlődésének mértéke. Az edzők, gyógypeda- 
gógusok a kapott eredmények tükrében tervezhetik meg a fejlesztő tevékenységet, tüzhetik ki a fejlesztési célokat.

Mivel a Kölyök Sportoló Program felmérő lapjának pontjai közvetlenül mérik azokat a képességeket, készségeket, amelyek a Kölyök Sportoló Program tananyagát képezik, ezért az eszköz tananyag-alapú értékelő eszköznek számít. A kifejezés, hogy tananyag-alapú értékelő vagy mérőeszköz olyan felmérésre utal, amely „közvetlenül megfigyeli és rögzíti a diák teljesítményét a helyi tananyag tükrében" (Deno, 1993; Witt, Elliot, Daly, Gresham \& Kramer, 1998).

A Kölyök Sportoló motoros értékelésnek három kulcseleme van:

1. Kölyök Sportoló Program elözetes értékelés

A Kölyök Sportoló Program előzetes értékelést a Kölyök Sportoló Programon való részvétel előtt kell lefolytatni. Ez a felmérés információt nyújt arról, hogy a Kölyök Sportoló Program megkezdése előtt a gyerekek milyen képességekkel, készségekkel rendelkeznek az egyensúlyérzék, járás, futás, ugrás és a manipulációs gyakorlatok konkrét kivitelezése területén.

2. Kölyök Sportoló Program utólagos értékelés

A Kölyök Sportoló Program utólagos értékelést a Kölyök Sportoló Programon való részvétel után kell lefolytatni. Hazai viszonylatban, mivel iskolai modell keretében valósul meg a program, érdemes tanév elején, illetve a tanév végén elvégezni a mérést. Ez a felmérés információt nyújt arról, hogy ugyanazon gyakorlatokban a fejlesztési időszak végén hogyan teljesítenek a gyermekek.

3. Kölyök Sportoló Program összehasonlító értékelés

Ez az összehasonlító értékelés olyan eszköz a felkészítő kezében, amellyel összehasonlíthatja az előzetes és utólagos adatokat, így nyomon követhető a fejlődés mértéke.

A Kölyök Sportoló Program felmérő lapja nem sztenderd mérőeszköz és nem használható az itt leírttól eltérő célra. Például azt nem javasoljuk, hogy a gyermek egyéni fejlesztési tervében, vagy fogyatékosság diagnózisában szerepeljenek a felmérés adatai, illetve, hogy a pontszámokat fejlődési mérföldkövekkel azonosítsák. $\mathrm{Az}$ eszközt nem ilyen megbízhatósággal és érvényességgel terveztük ezért nem használható a célján, vagyis a gyerekek méréskor mutatott képességeinek értékelésén kívül másra.

\section{A felméréshez szükséges eszközök}

A következő eszközök szükségesek a Kölyök Sportoló Program felmérő lapjának elvégzéséhez. Amennyiben nem rendelkezik az alábbi eszközökkel, bármilyen más, a célra alkalmas eszközzel helyettesíthető.

1. mérőszalag

2. stopperóra

3. széles szalag/vonal, vagy fejlesztő pálya jelölésére a padlón

4. közepes labda méretü elkapáshoz és rúgáshoz (kb. 4-es méretü futball labda)

5. kisméretű labda (kb. teniszlabda méretű)

6. zsámoly

7. kendő 


\section{KÖLYÖK SPORTOLÓ PROGRAM ELŐZETES ÉRTÉKELÉS}

A következő felmérést a gyermek Kölyök Sportoló Programon való részvételét megelőzően kell lefolytatni. Minden gyereket lehetőség szerint egyénileg kell felmérni, hogy csökkentsük a figyelem elterelődését és pontos eredményeket rögzíthessünk. A felmérés gyerekenként 15-20 percet vesz igénybe. Elsőként a felmérés folyamatát kell ismertetni a gyerekkel. Javasoljuk a következő szöveg használatát: „, Ma játékokat fogunk játszani. Elöször elmagyarázom, aztán megmutatom, hogy mit szeretnék, ha te megcsinálnál. Aztán te következel, csináld, amit én csináltam. Ha nem érted, mit kell csinálni, megmutatom megint. Az a lényeg, hogy csináld, amilyen jól csak tudod és érezd jól magad! Egy része könnyü lesz, más része lehet, hogy nehezebb, csak mindig próbáld a legjobban megcsinálni, amit kérek."

Kezdjük az első ponttal. Hangosan magyarázzuk el és aztán mutassuk be a gyereknek a feladatot. Ha nem érti meg, magyarázzuk el és mutassuk be azt másodszor is. A felmérés vezetője minden egyes pontban biztosítson két lehetőséget, hogy a gyerek teljesíthesse a feladatot és aztán rögzítse a legjobb eredményt. Ha a gyerek egy feladatot nem tud végrehajtani, válasszuk az N/A mezőt és lépjünk a következő feladatra. Ha az N/A mezőt választjuk, adat ne kerüljön a táblázatba.

Az értékelés megkezdése előtt jegyezzük fel az alábbi adatokat:

Dátum: Gyerek neve:

Gyerek kora:

Milyen a gyerek hozzáállása/hangulata ma? A keretben jegyezzünk fel minden olyan tényezőt, ami befolyásolhatja a gyerek képességét/lehetőségét, hogy a gyerek a képességeihez képest a legjobb teljesítményt nyújtsa.

\begin{tabular}{|c|c|c|c|c|c|}
\hline & Feladat & Eljárás/gyakorlatok & & & \\
\hline \multirow{2}{*}{ 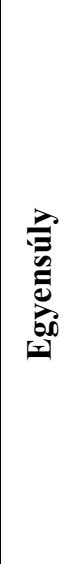 } & \multirow{2}{*}{$\begin{array}{c}1 . \\
\text { Állás egy } \\
\text { lábon }\end{array}$} & $\begin{array}{l}\text { Mutassuk be az egy lábon } \\
\text { állást mell elött keresztezett } \\
\text { karral, másik láb térdben } \\
\text { behajlítva. } \\
\text { Álljon a gyerek mell előtt } \\
\text { keresztezett karral, másik } \\
\text { láb térdben behajlítva. }\end{array}$ & $\begin{array}{l}\text { Hány másod- } \\
\text { percig tudott } \\
\text { a gyerek jobb } \\
\text { lábon állni? }\end{array}$ & $\mathrm{mp}$ & N/A \\
\hline & & $\begin{array}{l}\text { Használjunk stoppert, hogy } \\
\text { feljegyezzük, mennyi ideig } \\
\text { tud a gyerek egy lábon állni. } \\
30 \text { másodpercnél állítsuk } \\
\text { meg a mérést. } \\
\text { Ismételjük meg a másik } \\
\text { lábon állva. }\end{array}$ & $\begin{array}{l}\text { Hány másod- } \\
\text { percig tudott } \\
\text { a gyerek bal } \\
\text { lábon állni? }\end{array}$ & $\mathrm{mp}$ & $\mathrm{N} / \mathrm{A}$ \\
\hline
\end{tabular}




\begin{tabular}{|c|c|c|c|c|c|}
\hline & $\begin{array}{c}2 . \\
\text { Állás lábujj- } \\
\text { hegyen }\end{array}$ & $\begin{array}{l}\text { Mutassuk be a lábujjhegyen } \\
\text { állást kezünket a fej fölé } \\
\text { emelve. } \\
\text { Álljon a gyerek lábujjhegyen } \\
\text { kezeit a feje fölé emelve. } \\
\text { Használjunk stoppert, hogy } \\
\text { feljegyezzük, mennyi ideig } \\
\text { tud a gyerek lábujjhegyen } \\
\text { állni. } 30 \text { másodpercnél állít- } \\
\text { suk meg a mérést. }\end{array}$ & $\begin{array}{l}\text { Hány másod- } \\
\text { percig tudott } \\
\text { a gyerek } \\
\text { lábujjhegyen } \\
\text { állni? }\end{array}$ & $\mathrm{mp}$ & N/A \\
\hline \multirow{5}{*}{ 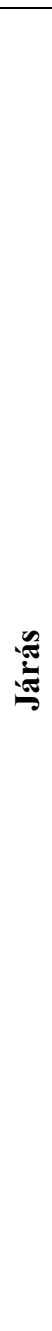 } & & \multirow{2}{*}{$\begin{array}{l}\text { Mutassuk be a járást vona- } \\
\text { lon egyik lábunkat a másik } \\
\text { elé helyezve. } \\
\text { A gyerek járjon egyenes } \\
\text { vonalon, próbálja mindkét } \\
\text { lábbal a vonalon maradni. } \\
\text { Jegyezzük fel, hogy } 0,1 \text {, } \\
\text { vagy } 2 \text { lábbal tudott a vona- } \\
\text { lon maradni. } \\
\text { Jegyezzük fel, hogy mekko- } \\
\text { ra távolságot tudott } 1 \text {, vagy } \\
2 \text { lábbal a vonalon megtenni. }\end{array}$} & $\begin{array}{l}\text { Hány lábbal } \\
\text { tudott a gye- } \\
\text { rek a vonalon } \\
\text { maradni? }\end{array}$ & 012 & N/A \\
\hline & $\begin{array}{c}1 . \\
\text { Járás egye- } \\
\text { nes vonalon }\end{array}$ & & $\begin{array}{l}\text { Mekkora } \\
\text { távolságot } \\
\text { tudott } 1 \text {, vagy } \\
2 \text { lábbal a } \\
\text { vonalon } \\
\text { megtenni? }\end{array}$ & méter & N/A \\
\hline & $\begin{array}{c}2 . \\
\text { Járás és tárgy } \\
\text { szállítása }\end{array}$ & $\begin{array}{l}\text { A gyerek egy közepes mére- } \\
\text { tú tárgyat szállítva sétáljon. } \\
\text { Jegyezzük fel, hogy mekko- } \\
\text { ra távolságon tudott tárgyat } \\
\text { szállítva sétálni max. } 25 \\
\text { méterig. }\end{array}$ & $\begin{array}{l}\text { Mekkora } \\
\text { távolságot } \\
\text { tudott meg- } \\
\text { tenni a gye- } \\
\text { rek? }\end{array}$ & méter & $\mathrm{N} / \mathrm{A}$ \\
\hline & $\begin{array}{c}3 . \\
\text { Lépés olda- } \\
\text { lazva }\end{array}$ & $\begin{array}{l}\text { Mutassuk be a járást olda- } \\
\text { lazva vonal mentén. } \\
\text { A gyerek járjon oldalazva } \\
\text { vonal mentén. } \\
\text { Jegyezzük fel, hogy mekko- } \\
\text { ra távolságon tudott a gye- } \\
\text { rek oldalazva vonal mentén } \\
\text { járni max. } 5 \text { méterig. }\end{array}$ & $\begin{array}{l}\text { Mekkora } \\
\text { távolságot } \\
\text { tudott meg- } \\
\text { tenni a gye- } \\
\text { rek? }\end{array}$ & _méter & $\mathrm{N} / \mathrm{A}$ \\
\hline & $\begin{array}{l}4 . \\
\text { Lépés hátra- } \\
\text { felé }\end{array}$ & $\begin{array}{l}\text { Mutassuk be a hátrafelé } \\
\text { járást. } \\
\text { A gyerek járjon hátrafelé. } \\
\text { Jegyezzük fel, hogy mekko- } \\
\text { ra távolságon tudott a gye- } \\
\text { rek hátra lépéssel járni max. } \\
5 \text { méterig? }\end{array}$ & $\begin{array}{l}\text { Mekkora } \\
\text { távolságot } \\
\text { tudott meg- } \\
\text { tenni a gye- } \\
\text { rek? }\end{array}$ & méter & $\mathrm{N} / \mathrm{A}$ \\
\hline
\end{tabular}




\begin{tabular}{|c|c|c|c|c|c|}
\hline & Feladat & Eljárás/gyakorlatok & \multicolumn{3}{|c|}{ Értékelés } \\
\hline \multirow{5}{*}{ 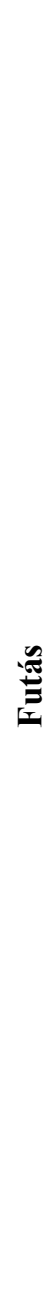 } & \multirow{3}{*}{$\begin{array}{l}1 . \\
\text { Futómozgás }\end{array}$} & \multirow{3}{*}{$\begin{array}{c}\text { A gyerek fusson legalább } \\
15 \text { métert. } \\
\text { Jegyezzük fel, hogy a } \\
\text { gyerek } \\
\text { tud-e futni. } \\
\text { (egy pillanatra mindkét } \\
\text { láb egy időben elemelke- } \\
\text { dik a földtől) } \\
\text { Jegyezzük fel, hogy a } \\
\text { gyerek karjai hol helyez- } \\
\text { kednek el testéhez képest } \\
\text { futáskor. }\end{array}$} & $\begin{array}{c}\text { Tud a gyerek fut- } \\
\text { ni? } \\
\text { (megfelelő válasz } \\
\text { bejelölendö) }\end{array}$ & $\begin{array}{l}\square \text { Igen } \\
\square \text { Nem }\end{array}$ & $\begin{array}{c}\square \\
\text { N/A }\end{array}$ \\
\hline & & & $\begin{array}{l}\text { A gyerek teletal- } \\
\text { pon vagy a talp- } \\
\text { párnáin fut? } \\
\text { (megfelelö válasz } \\
\text { bejelölendö) }\end{array}$ & $\begin{array}{l} \\
\text { teletal- } \\
\text { pon } \\
\square \\
\text { talp- } \\
\text { párnáin }\end{array}$ & $\begin{array}{c}\square \\
\mathrm{N} / \mathrm{A}\end{array}$ \\
\hline & & & $\begin{array}{l}\text { Hol vannak a gye- } \\
\text { rek karjai? } \\
\text { (megfelelő válasz } \\
\text { bejelölendő) }\end{array}$ & $\begin{array}{c}\mathrm{a} \\
\text { test } \\
\text { mellett } \\
\square \mathrm{a} \\
\text { test } \\
\text { elött } \\
\square \\
\text { előre- } \\
\text { hátra } \\
\text { mo- } \\
\text { zognak }\end{array}$ & $\begin{array}{c}\square \\
\mathrm{N} / \mathrm{A}\end{array}$ \\
\hline & $\begin{array}{l}2 . \\
\text { Futás sebes- } \\
\text { sége rövid } \\
\text { távon }\end{array}$ & $\begin{array}{l}\text { A gyerek fusson } 5 \text { métert. } \\
\text { Használjunk stoppert, } \\
\text { hogy feljegyezzük, mennyi } \\
\text { ideig tart a gyereknek az } 5 \\
\text { méter lefutása. }\end{array}$ & $\begin{array}{c}\text { Hány másodpercbe } \\
\text { került az } 5 \text { méter } \\
\text { lefutása? }\end{array}$ & $\mathrm{mp}$ & $\begin{array}{c}\square \\
\mathrm{N} / \mathrm{A}\end{array}$ \\
\hline & $\begin{array}{l}3 . \\
\text { Futás sebes- } \\
\text { sége hosszú } \\
\text { távon }\end{array}$ & $\begin{array}{l}\text { A gyerek fusson } 10 \text { métert. } \\
\text { Használjunk stoppert, } \\
\text { hogy feljegyezzük, mennyi } \\
\text { ideig tart a gyereknek a } 10 \\
\text { méter lefutása. }\end{array}$ & $\begin{array}{c}\text { Hány másodpercbe } \\
\text { került a } 10 \text { méter } \\
\text { lefutása? }\end{array}$ & $\mathrm{mp}$ & $\begin{array}{c}\square \\
\mathrm{N} / \mathrm{A}\end{array}$ \\
\hline (2) & $\begin{array}{c}1 . \\
\text { Leugrás }\end{array}$ & $\begin{array}{l}\text { Mutassuk be a leugrást } \\
\text { zsámolyról páros lábra } \\
\text { érkezéssel. } \\
\text { A gyerek ugorjon le a } \\
\text { zsámolyról. } \\
\text { Jegyezzük fel, hogy páros } \\
\text { lábra érkezett-e. }\end{array}$ & $\begin{array}{c}\text { Tudott páros ábra } \\
\text { érkezni? }\end{array}$ & $\begin{array}{l}\square \text { Igen } \\
\square \text { Nem }\end{array}$ & $\begin{array}{c}\square \\
\mathrm{N} / \mathrm{A}\end{array}$ \\
\hline
\end{tabular}




\begin{tabular}{|c|c|c|c|c|}
\hline \multirow{2}{*}{$\begin{array}{c}2 . \\
\text { Elöre ugrás }\end{array}$} & \multirow{2}{*}{$\begin{array}{c}\text { Mutassuk be az előre ug- } \\
\text { rást páros lábbal elrugasz- } \\
\text { kodva és páros lábra ér- } \\
\text { kezve. } \\
\text { A gyerek ugorjon, előre } \\
\text { amilyen messzire tud. } \\
\text { Jegyezzük fel a távolságot, } \\
\text { és hogy a gyerek páros } \\
\text { lábbal elrugaszkodva és } \\
\text { páros lábra érkezve ugrott- } \\
\text { e. }\end{array}$} & $\begin{array}{l}\text { Mekkorát tudott } \\
\text { ugrani a gyerek? }\end{array}$ & $\begin{array}{l}\text { centi- } \\
\text { méter }\end{array}$ & $\begin{array}{c}\square \\
\mathrm{N} / \mathrm{A}\end{array}$ \\
\hline & & $\begin{array}{l}\text { Mindkét lábbal } \\
\text { egyenlően elru- } \\
\text { gaszkodva és páros } \\
\text { lábra érkezve ug- } \\
\text { rott a gyerek? }\end{array}$ & $\begin{array}{l}\square \text { Igen } \\
\square \text { Nem }\end{array}$ & $\begin{array}{c}\square \\
\mathrm{N} / \mathrm{A}\end{array}$ \\
\hline \multirow{2}{*}{$\begin{array}{c}3 . \\
\text { Magas ugrás }\end{array}$} & \multirow{2}{*}{$\begin{array}{c}\text { Mutassuk be a magas } \\
\text { ugrást páros lábbal elru- } \\
\text { gaszkodva és páros lábra } \\
\text { érkezve. } \\
\text { A gyerek ugorjon, olyan } \\
\text { magasra amilyen magasra } \\
\text { tud. } \\
\text { Jegyezzük fel a magassá- } \\
\text { got, és hogy a gyerek } \\
\text { páros lábbal elrugaszkodva } \\
\text { és páros lábra érkezve } \\
\text { ugrott-e. }\end{array}$} & $\begin{array}{l}\text { Mekkorát tudott } \\
\text { ugrani a gyerek? }\end{array}$ & $\mathrm{cm}$ & $\begin{array}{c}\square \\
\mathrm{N} / \mathrm{A}\end{array}$ \\
\hline & & $\begin{array}{l}\text { Páros lábbal elru- } \\
\text { gaszkodva és páros } \\
\text { lábra érkezve ug- } \\
\text { rott a gyerek? }\end{array}$ & $\begin{array}{l}\square \text { Igen } \\
\square \text { Nem }\end{array}$ & $\begin{array}{c}\square \\
\mathrm{N} / \mathrm{A}\end{array}$ \\
\hline $\begin{array}{l}4 . \\
\text { Egy lábon } \\
\text { ugrálás }\end{array}$ & $\begin{array}{c}\text { Mutassuk be az egy lábon } \\
\text { ugrálást anélkül, hogy } \\
\text { letennénk a másik lábun- } \\
\text { kat. } \\
\text { A gyerek ugráljon egy } \\
\text { lábon. } \\
\text { Jegyezzük fel, hogy a } \\
\text { gyerek hányat tudott egy } \\
\text { lábon ugrani? }\end{array}$ & $\begin{array}{l}\text { Hányat tudott egy } \\
\text { lábon ugrani a } \\
\text { gyerek? }\end{array}$ & ugrás & $\begin{array}{c}\square \\
\mathrm{N} / \mathrm{A}\end{array}$ \\
\hline
\end{tabular}




\begin{tabular}{|c|c|c|c|c|c|}
\hline & Feladat & \multirow{2}{*}{$\begin{array}{c}\text { Eljárás/gyakorlatok } \\
\text { A földön terpeszülésben } \\
\text { gurítsuk egy méterre a } \\
\text { labdát a szemben ugyan- } \\
\text { ilyen testtartásban ülö } \\
\text { gyereknek. } \\
\text { Jegyezzük fel, hogy a } \\
\text { gyerek vissza tudta-e gurí- } \\
\text { tani a labdát? }\end{array}$} & \multicolumn{3}{|c|}{ Értékelés } \\
\hline \multirow{6}{*}{ 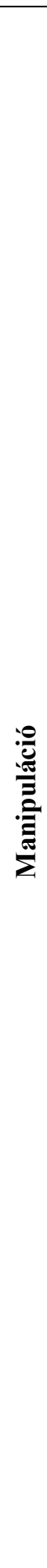 } & $\begin{array}{l}1 . \\
\text { Labda } \\
\text { gurítás }\end{array}$ & & $\begin{array}{l}\text { Vissza tudta guríta- } \\
\text { ni a gyerek a lab- } \\
\text { dát? }\end{array}$ & $\begin{array}{l}\square \text { Igen } \\
\square \text { Nem }\end{array}$ & $\begin{array}{c}\square \\
\mathrm{N} / \mathrm{A}\end{array}$ \\
\hline & $\begin{array}{c}2 . \\
\text { Kendö } \\
\text { felemelése }\end{array}$ & $\begin{array}{l}\text { Kérjük meg a gyereket, } \\
\text { hogy vegyen fel a kendőt. }\end{array}$ & $\begin{array}{l}\text { Hogyan vette fel a } \\
\text { gyerek a kendőt? }\end{array}$ & $\begin{array}{c} \\
\text { ujjakkal } \\
\text { és te- } \\
\text { nyérrel } \\
\square \\
3 \text { vagy } \\
\text { több ujjal } \\
\square \\
2 \\
\text { ujjbegy- } \\
\text { gyel } \\
\end{array}$ & $\begin{array}{c}\square \\
\mathrm{N} / \mathrm{A}\end{array}$ \\
\hline & 3. & $\begin{array}{c}\text { Álló testhelyzetben dobjuk } \\
\text { a közepes méretü labdát a } \\
\text { gyereknek mellmagasság- } \\
\text { ban. }\end{array}$ & $\begin{array}{l}\text { Nyújtotta a gyerek } \\
\text { a kezét, hogy elkap- } \\
\text { ja a labdát? }\end{array}$ & $\begin{array}{l}\square \text { Igen } \\
\square \text { Nem }\end{array}$ & $\begin{array}{c}\square \\
\mathrm{N} / \mathrm{A}\end{array}$ \\
\hline & elkapása & $\begin{array}{l}\text { gyerek nyújtja-e a kezét, } \\
\text { hogy elkapja a labdát. } \\
\text { Jegyezzük fel, hogy a } \\
\text { gyerek elkapja-e a labdát. }\end{array}$ & $\begin{array}{l}\text { Sikerült elkapnia a } \\
\text { labdát? }\end{array}$ & $\begin{array}{l}\text { पIgen } \\
\square \mathrm{Nem}\end{array}$ & $\begin{array}{c}\square \\
\text { N/A }\end{array}$ \\
\hline & $\begin{array}{l}4 . \\
\text { Alsó egy- } \\
\text { kezes } \\
\text { dobás }\end{array}$ & $\begin{array}{c}\text { Mutassuk be kisméretü } \\
\text { labda alsó egykezes dobá- } \\
\text { sát legalább három méter- } \\
\text { re. } \\
\text { A gyerek dobja a labdát } \\
\text { alsó egykezes dobással. } \\
\text { Jegyezzük fel, milyen } \\
\text { messzire dobja a gyerek a } \\
\text { labdát. }\end{array}$ & $\begin{array}{l}\text { Milyen messzire } \\
\text { tudta dobni a gye- } \\
\text { rek a labdát? }\end{array}$ & $\overline{\text { méter }}$ & $\begin{array}{c}\square \\
\mathrm{N} / \mathrm{A}\end{array}$ \\
\hline & $\begin{array}{l}5 . \\
\text { Felső egy- } \\
\text { kezes } \\
\text { dobás }\end{array}$ & $\begin{array}{c}\text { Mutassuk be kisméretü } \\
\text { labda felső egykezes dobá- } \\
\text { sát legalább három méter- } \\
\text { re. } \\
\text { A gyerek dobja a labdát } \\
\text { felső egykezes dobással. } \\
\text { Jegyezzük fel, milyen } \\
\text { messzire dobja a gyerek a } \\
\text { labdát. }\end{array}$ & $\begin{array}{l}\text { Milyen messzire } \\
\text { tudta dobni a gye- } \\
\text { rek a labdát? }\end{array}$ & méter & $\begin{array}{c}\square \\
\mathrm{N} / \mathrm{A}\end{array}$ \\
\hline
\end{tabular}




\begin{tabular}{|c|c|c|c|c|}
\hline $\begin{array}{c}6 . \\
\text { Rúgás }\end{array}$ & $\begin{array}{l}\text { Mutassuk be álló, közepes } \\
\text { méretű labda rúgását leg- } \\
\text { alább négy méterre. } \\
\text { A gyerek rúgja el az álló } \\
\text { labdát amilyen messzire } \\
\text { tudja. } \\
\text { Jegyezzük fel, milyen mesz- } \\
\text { szire rúgja a gyerek a labdát. }\end{array}$ & $\begin{array}{c}\text { Milyen messzire } \\
\text { tudta rúgni a gyerek } \\
\text { a labdát? }\end{array}$ & méter & $\begin{array}{c}\square \\
\text { N/A }\end{array}$ \\
\hline $\begin{array}{l}7 . \\
\text { Guruló } \\
\text { labda } \\
\text { rúgása }\end{array}$ & $\begin{array}{l}\text { Mutassuk be a guruló } \\
\text { labda rúgását, amelyet a } \\
\text { rúgó felé gurítottak } \\
\text { Gurítsunk labdát a gyerek } \\
\text { felé, a gyerek rúgja, a } \\
\text { labdát amilyen messzire } \\
\text { tudja. } \\
\text {-- Jegyezzük fel, milyen } \\
\text { messzire rúgja a gyerek a } \\
\text { labdát. }\end{array}$ & $\begin{array}{l}\text { Milyen messzire } \\
\text { tudta rúgni a gyerek } \\
\text { a labdát? }\end{array}$ & méter & $\begin{array}{r}\square \\
\text { N/A }\end{array}$ \\
\hline
\end{tabular}

\section{KÖLYÖK SPORTOLÓ PROGRAM UTÓLAGOS ÉRTÉKELÉS}

A következő felmérést a gyermek Kölyök Sportoló Programon való részvételét követően, vagy a fejlesztési időszak végén - hazai viszonylatban tanév végén- kell lefolytatni.

Minden gyereket lehetőség szerint egyénileg kell felmérni, hogy csökkentsük a figyelem elterelődését és pontos eredményeket rögzíthessünk. A felmérés gyerekenként 15-20 percet vesz igénybe. Elsőként a felmérés folyamatát kell ismertetni a gyerekkel. Javasoljuk a következő szöveg használatát:

„Ma játékokat fogunk játszani. Elöször elmagyarázom, aztán megmutatom, hogy mit szeretnék, ha te megcsinálnál. Aztán te következel, csináld, amit én csináltam. Ha nem érted, mit kell csinálni, megmutatom megint. Az a lényeg, hogy csináld, amennyire csak tudod és érezd jól magad! Egy része könnyü lesz, más része lehet, hogy nehezebb, csak mindig próbáld a legjobban megcsinálni, amit kérek."

Kezdjük az első ponttal. Hangosan magyarázzuk el és aztán mutassuk be a gyereknek a feladatot. Ha nem érti meg, magyarázzuk el és mutassuk be azt másodszor is. A felmérés vezetője minden egyes pontban biztosítson két lehetőséget, hogy a gyerek teljesíthesse a feladatot és aztán rögzítse a legjobb eredményt. Ha a gyerek egy feladatot nem tud végrehajtani, válasszuk az N/A mezöt és lépjünk a következő feladatra. Ha az N/A mezőt választjuk, adat ne kerüljön a táblázatba.

Az értékelés megkezdése előtt jegyezzük fel az alábbi adatokat:

Dátum: Gyerek neve:

Gyerek kora:

Hány hétig vett részt a gyerek a Kölyök Sportoló Programban?

Milyen a gyerek hozzáállása/hangulata ma? A keretben jegyezzünk fel minden olyan tényezőt, ami befolyásolhatja a gyerek képességét/lehetőségét, hogy a gyerek a képességeihez képest a legjobb teljesítményt nyújtsa. 


\begin{tabular}{|c|c|c|c|c|c|}
\hline & Feladat & Eljárás/gyakorlatok & Érté & lés & \\
\hline \multirow{3}{*}{ 㐘 } & \multirow{2}{*}{$\begin{array}{l}1 . \\
\text { Állás egy } \\
\text { lábon }\end{array}$} & \multirow{2}{*}{$\begin{array}{l}\text { Mutassuk be az egy lábon állást } \\
\text { mell elött keresztezett karral, } \\
\text { másik láb térdben behajlítva. } \\
\text { Álljon a gyerek mell elött ke- } \\
\text { resztezett karral, másik láb } \\
\text { térdben behajlítva. } \\
\text { Használjunk stoppert, hogy } \\
\text { feljegyezzük, mennyi ideig tud } \\
\text { a gyerek egy lábon állni. } 30 \\
\text { másodpercnél állítsuk meg a } \\
\text { mérést. } \\
\text { Ismételjük meg a másik lábon } \\
\text { állva. }\end{array}$} & $\begin{array}{l}\text { Hány másod- } \\
\text { percig tudott a } \\
\text { gyerek jobb } \\
\text { lábon állni? }\end{array}$ & $\mathrm{mp}$ & $\mathrm{N} / \mathrm{A}$ \\
\hline & & & $\begin{array}{l}\text { Hány másod- } \\
\text { percig tudott a } \\
\text { gyerek bal } \\
\text { lábon állni? }\end{array}$ & $\mathrm{mp}$ & N/A \\
\hline & $\begin{array}{l}2 . \\
\text { Állás lábujj- } \\
\text { hegyen }\end{array}$ & $\begin{array}{l}\text { Mutassuk be a lábujjhegyen } \\
\text { állást kezünket a fej fölé emelve. } \\
\text { Álljon a gyerek lábujjhegyen } \\
\text { kezeit a feje fölé emelve. } \\
\text { Használjunk stoppert, hogy } \\
\text { feljegyezzük, mennyi ideig tud } \\
\text { a gyerek lábujjhegyen állni. } 30 \\
\text { másodpercnél állítsuk meg a } \\
\text { mérést. }\end{array}$ & $\begin{array}{l}\text { Hány másod- } \\
\text { percig tudott a } \\
\text { gyerek lábujj- } \\
\text { hegyen állni? }\end{array}$ & $\mathrm{mp}$ & $\mathrm{N} / \mathrm{A}$ \\
\hline \multirow{4}{*}{ 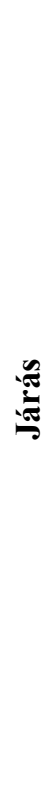 } & \multirow[b]{2}{*}{$\begin{array}{l}1 . \\
\text { Járás egyenes } \\
\text { vonalon }\end{array}$} & \multirow{2}{*}{$\begin{array}{l}\text { Mutassuk be a járást vonalon } \\
\text { egyik lábunkat a másik elé } \\
\text { helyezve. } \\
\text { A gyerek járjon egyenes vona- } \\
\text { lon, próbálja mindkét lábbal a } \\
\text { vonalon maradni. } \\
\text { Jegyezzük fel, hogy } 0,1 \text {, vagy } 2 \\
\text { lábbal tudott a vonalon maradni. } \\
\text { Jegyezzük fel, hogy mekkora } \\
\text { távolságot tudott } 1 \text {, vagy } 2 \\
\text { lábbal a vonalon megtenni. }\end{array}$} & $\begin{array}{l}\text { Hány lábbal } \\
\text { tudott a gyerek } \\
\text { a vonalon ma- } \\
\text { radni? }\end{array}$ & 012 & $\mathrm{~N} / \mathrm{A}$ \\
\hline & & & $\begin{array}{l}\text { Mekkora távol- } \\
\text { ságot tudott } 1 \text {, } \\
\text { vagy } 2 \text { lábbal a } \\
\text { vonalon meg- } \\
\text { tenni? }\end{array}$ & méter & $\mathrm{N} / \mathrm{A}$ \\
\hline & $\begin{array}{l}2 . \\
\text { Járás és tárgy } \\
\text { szállítása }\end{array}$ & $\begin{array}{l}\text { A gyerek egy közepes méretü } \\
\text { tárgyat szállítva sétáljon. } \\
\text { Jegyezzük fel, hogy mekkora } \\
\text { távolságon tudott tárgyat szál- } \\
\text { lítva sétálni max. } 25 \text { méterig. }\end{array}$ & $\begin{array}{l}\text { Mekkora távol- } \\
\text { ságot tudott } \\
\text { megtenni a } \\
\text { gyerek? }\end{array}$ & méter & $\mathrm{N} / \mathrm{A}$ \\
\hline & $\begin{array}{l}3 . \\
\text { Lépés olda- } \\
\text { lazva }\end{array}$ & $\begin{array}{l}\text { Mutassuk be a járást oldalazva } \\
\text { vonal mentén. } \\
\text { A gyerek járjon oldalazva vonal } \\
\text { mentén. }\end{array}$ & $\begin{array}{l}\text { Mekkora távol- } \\
\text { ságot tudott } \\
\text { megtenni a } \\
\text { gyerek? }\end{array}$ & ${ }^{-}$méter ${ }^{-}$ & $\mathrm{N} / \mathrm{A}$ \\
\hline
\end{tabular}




\begin{tabular}{|c|c|c|c|c|}
\hline & $\begin{array}{l}\text { Jegyezzük fel, hogy mekkora } \\
\text { távolságon tudott a gyerek } \\
\text { oldalazva vonal mentén járni } \\
\text { max. } 5 \text { méterig. }\end{array}$ & & & \\
\hline $\begin{array}{l}4 . \\
\text { Lépés hátra- } \\
\text { felé }\end{array}$ & $\begin{array}{l}\text { Mutassuk be a hátrafelé járást. } \\
\text { A gyerek járjon hátrafelé. } \\
\text { Jegyezzük fel, hogy mekkora } \\
\text { távolságon tudott a gyerek hátra } \\
\text { lépéssel járni max. } 5 \text { méterig? }\end{array}$ & $\begin{array}{l}\text { Mekkora távol- } \\
\text { ságot tudott } \\
\text { megtenni a } \\
\text { gyerek? }\end{array}$ & méter & N/A \\
\hline
\end{tabular}

\begin{tabular}{|c|c|c|c|c|c|}
\hline & Feladat & Eljárás/gyakorlatok & \multicolumn{3}{|c|}{ Értékelés } \\
\hline \multirow{5}{*}{ 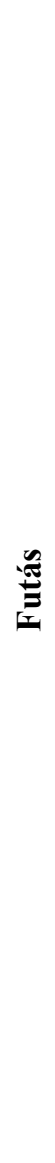 } & \multirow{3}{*}{$\begin{array}{l}1 . \\
\text { Futómozgás }\end{array}$} & \multirow{3}{*}{$\begin{array}{c}\text { A gyerek fusson legalább } 15 \\
\text { métert. } \\
\text { Jegyezzük fel, hogy a gyerek } \\
\text { tud-e futni. } \\
\text { (egy pillanatra mindkét láb } \\
\text { egy időben elemelkedik a föld- } \\
\text { től) }\end{array}$} & $\begin{array}{l}\text { Tud a gyerek } \\
\text { futni? } \\
\text { (megfelelő } \\
\text { válasz bejelö- } \\
\text { lendő) }\end{array}$ & $\begin{array}{l}\square \text { Igen } \\
\square \text { Nem }\end{array}$ & $\underset{\mathrm{N} / \mathrm{A}}{\square}$ \\
\hline & & & $\begin{array}{l}\text { A gyerek } \\
\text { teletalpon } \\
\text { vagy a talp- } \\
\text { párnáin fut? } \\
\text { (megfelelö } \\
\text { válasz bejelö- } \\
\text { lendö) }\end{array}$ & $\begin{array}{l}\square \text { tele- } \\
\text { talpon } \\
\square \\
\text { talppár- } \\
\text { náin }\end{array}$ & $\begin{array}{c}\square \\
\mathrm{N} / \mathrm{A}\end{array}$ \\
\hline & & & $\begin{array}{l}\text { Hol vannak a } \\
\text { gyerek karjai? } \\
\text { (megfelelö } \\
\text { válasz bejelö- } \\
\text { lendö) }\end{array}$ & $\begin{array}{c}\square \text { a test } \\
\text { mellett } \\
\square \text { a test } \\
\text { elött } \\
\square \text { elöre- } \\
\text { hátra } \\
\text { mozog- } \\
\text { nak }\end{array}$ & $\begin{array}{c}\square \\
\mathrm{N} / \mathrm{A}\end{array}$ \\
\hline & $\begin{array}{l}2 . \\
\text { Futás sebes- } \\
\text { sége rövid } \\
\text { távon } \\
\end{array}$ & $\begin{array}{l}\text { A gyerek fusson } 5 \text { métert. } \\
\text { Használjunk stoppert, hogy } \\
\text { feljegyezzük, mennyi ideig tart } \\
\text { a gyereknek az } 5 \text { méter lefutása. }\end{array}$ & $\begin{array}{l}\text { Hány másod- } \\
\text { percbe került } \\
\text { az } 5 \text { méter } \\
\text { lefutása? }\end{array}$ & $\mathrm{mp}$ & $\begin{array}{c}\square \\
\mathrm{N} / \mathrm{A}\end{array}$ \\
\hline & $\begin{array}{l}3 . \\
\text { Futás sebes- } \\
\text { sége hosszú } \\
\text { távon }\end{array}$ & $\begin{array}{l}\text { A gyerek fusson } 10 \text { métert. } \\
\text { Használjunk stoppert, hogy } \\
\text { feljegyezzük, mennyi ideig tart } \\
\text { a gyereknek a } 10 \text { méter lefutása. }\end{array}$ & $\begin{array}{l}\text { Hány másod- } \\
\text { percbe került a } \\
10 \text { méter lefu- } \\
\text { tása? }\end{array}$ & $\mathrm{mp}$ & $\begin{array}{c}\square \\
\mathrm{N} / \mathrm{A}\end{array}$ \\
\hline (5) & $\begin{array}{c}1 . \\
\text { Leugrás }\end{array}$ & $\begin{array}{l}\text { Mutassuk be a leugrást zsá- } \\
\text { molyról páros lábra érkezéssel. } \\
\text { A gyerek ugorjon le a zsámoly- } \\
\text { ról. } \\
\text { Jegyezzük fel, hogy páros lábra } \\
\text { érkezett-e. }\end{array}$ & $\begin{array}{l}\text { Tudott páros } \\
\text { ábra érkezni? }\end{array}$ & $\begin{array}{l}\square \text { Igen } \\
\square \text { Nem }\end{array}$ & $\begin{array}{c}\square \\
\mathrm{N} / \mathrm{A}\end{array}$ \\
\hline
\end{tabular}




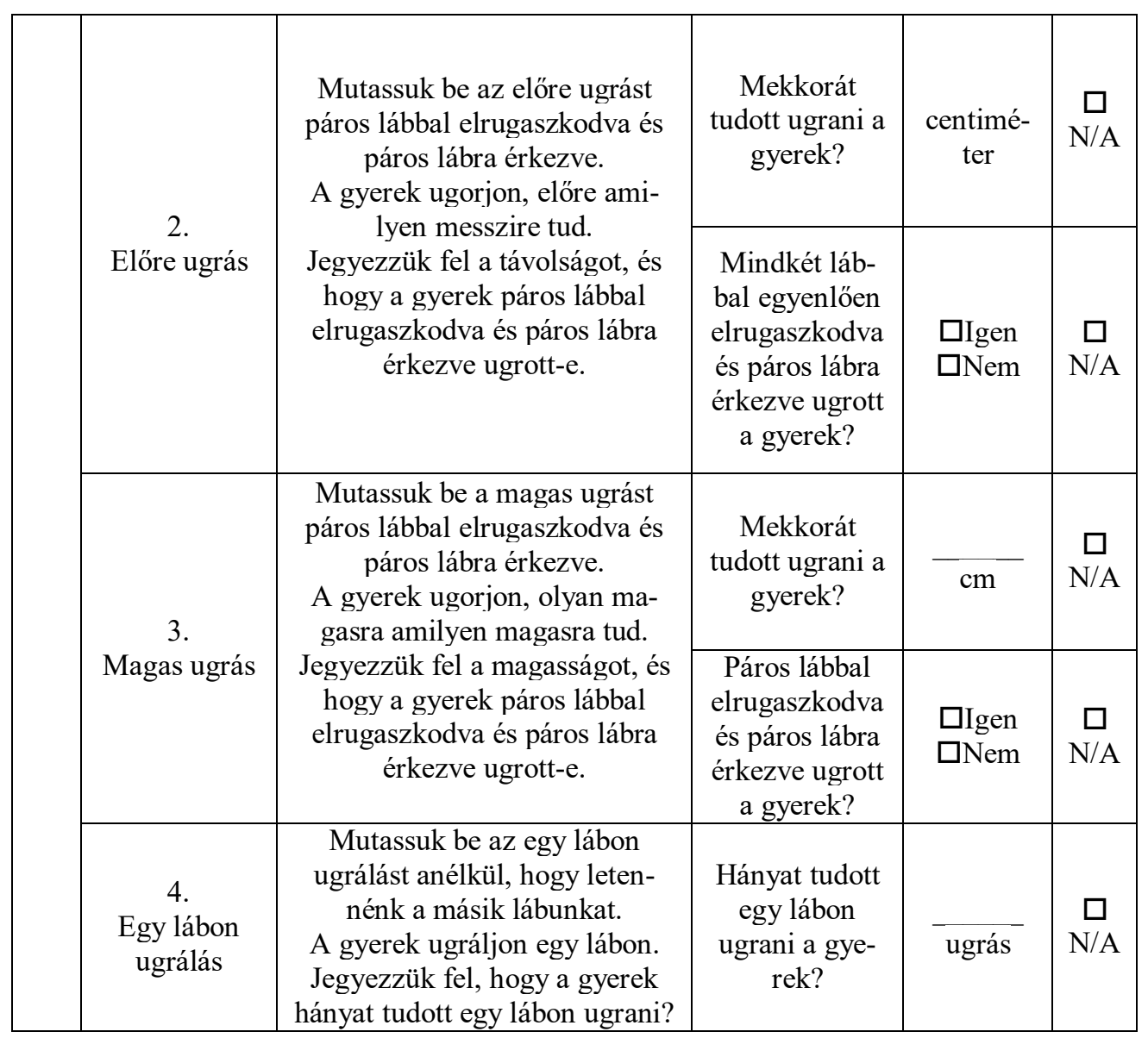

\begin{tabular}{|c|c|c|c|c|c|}
\hline & Feladat & Eljárás/gyakorlatok & & rtékelés & \\
\hline \multirow{2}{*}{ 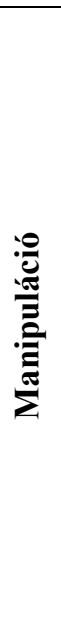 } & $\begin{array}{c}1 . \\
\text { Labda gurítás }\end{array}$ & $\begin{array}{l}\text { A földön terpeszülésben gurít- } \\
\text { suk egy méterre a labdát a } \\
\text { szemben ugyanilyen testtar- } \\
\text { tásban ülő gyereknek. } \\
\text { Jegyezzük fel, hogy a gyerek } \\
\text { vissza tudta-e gurítani a lab- } \\
\text { dát? } \\
\end{array}$ & $\begin{array}{l}\text { Vissza } \\
\text { tudta gurí- } \\
\text { tani a } \\
\text { gyerek a } \\
\text { labdát? }\end{array}$ & $\begin{array}{l}\square \text { Igen } \\
\square \text { Nem }\end{array}$ & $\square \mathrm{N} / \mathrm{A}$ \\
\hline & $\begin{array}{c}2 . \\
\text { Kendö fel- } \\
\text { emelése }\end{array}$ & $\begin{array}{l}\text { Kérjük meg a gyereket, hogy } \\
\text { vegyen fel a kendőt. }\end{array}$ & $\begin{array}{l}\text { Hogyan } \\
\text { vette fel a } \\
\text { gyerek a } \\
\text { kendőt? }\end{array}$ & $\begin{array}{c}\square \\
\text { ujjakkal és } \\
\text { tenyérrel } \\
\square \\
3 \text { vagy } \\
\text { több ujjal } \\
\square \\
2 \\
\text { ujjbeggyel }\end{array}$ & $\square \mathrm{N} / \mathrm{A}$ \\
\hline
\end{tabular}




\begin{tabular}{|c|c|c|c|c|}
\hline \multirow[t]{2}{*}{$\begin{array}{c}3 . \\
\text { Labda elkapá- } \\
\text { sa }\end{array}$} & \multirow{2}{*}{$\begin{array}{c}\text { Álló testhelyzetben dobjuk a } \\
\text { közepes méretü labdát a gye- } \\
\text { reknek mellmagasságban. } \\
\text { Jegyezzük fel, hogy a gyerek } \\
\text { nyújtja-e a kezét, hogy elkapja } \\
\text { a labdát. } \\
\text { Jegyezzük fel, hogy a gyerek } \\
\text { elkapja-e a labdát. }\end{array}$} & $\begin{array}{l}\text { Nyújtotta a } \\
\text { gyerek a } \\
\text { kezét, } \\
\text { hogy el- } \\
\text { kapja a } \\
\text { labdát? }\end{array}$ & $\begin{array}{l}\square \text { Igen } \\
\square \text { Nem }\end{array}$ & $\square \mathrm{N} / \mathrm{A}$ \\
\hline & & $\begin{array}{l}\text { Sikerült } \\
\text { elkapnia a } \\
\text { labdát? }\end{array}$ & $\begin{array}{l}\square \text { Igen } \\
\square \text { Nem }\end{array}$ & $\square \mathrm{N} / \mathrm{A}$ \\
\hline $\begin{array}{c}4 . \\
\text { Alsó egykezes } \\
\text { dobás }\end{array}$ & $\begin{array}{l}\text { Mutassuk be kisméretű labda } \\
\text { alsó egykezes dobását leg- } \\
\text { alább három méterre. } \\
\text { A gyerek dobja a labdát alsó } \\
\text { egykezes dobással. } \\
\text { Jegyezzük fel, milyen messzi- } \\
\text { re dobja a gyerek a labdát. }\end{array}$ & $\begin{array}{l}\text { Milyen } \\
\text { messzire } \\
\text { tudta dobni } \\
\text { a gyerek a } \\
\text { labdát? }\end{array}$ & méter & $\square \mathrm{N} / \mathrm{A}$ \\
\hline $\begin{array}{c}5 . \\
\text { Felső egyke- } \\
\text { zes dobás }\end{array}$ & $\begin{array}{l}\text { Mutassuk be kisméretű labda } \\
\text { felső egykezes dobását leg- } \\
\text { alább három méterre. } \\
\text { A gyerek dobja a labdát felső } \\
\text { egykezes dobással. } \\
\text { Jegyezzük fel, milyen messzi- } \\
\text { re dobja a gyerek a labdát. }\end{array}$ & $\begin{array}{l}\text { Milyen } \\
\text { messzire } \\
\text { tudta dobni } \\
\text { a gyerek a } \\
\text { labdát? }\end{array}$ & méter & $\square \mathrm{N} / \mathrm{A}$ \\
\hline $\begin{array}{c}6 . \\
\text { Rúgás }\end{array}$ & $\begin{array}{l}\text { Mutassuk be álló, közepes } \\
\text { méretü labda rúgását legalább } \\
\text { négy méterre. } \\
\text { A gyerek rúgja el az álló lab- } \\
\text { dát amilyen messzire tudja. } \\
\text { Jegyezzük fel, milyen messzi- } \\
\text { re rúgja a gyerek a labdát. }\end{array}$ & $\begin{array}{c}\text { Milyen } \\
\text { messzire } \\
\text { tudta rúgni } \\
\text { a gyerek a } \\
\text { labdát? }\end{array}$ & méter & $\square$ N/A \\
\hline $\begin{array}{l}7 . \\
\text { Guruló labda } \\
\text { rúgása }\end{array}$ & $\begin{array}{l}\text { Mutassuk be a guruló labda } \\
\text { rúgását, amelyet a rúgó felé } \\
\text { gurítottak } \\
\text { Gurítsunk labdát a gyerek felé, } \\
\text { a gyerek rúgja, a labdát ami- } \\
\text { lyen messzire tudja. } \\
\text { Jegyezzük fel, milyen messzi- } \\
\text { re rúgja a gyerek a labdát. }\end{array}$ & $\begin{array}{c}\text { Milyen } \\
\text { messzire } \\
\text { tudta rúgni } \\
\text { a gyerek a } \\
\text { labdát? }\end{array}$ & méter & $\square \mathrm{N} / \mathrm{A}$ \\
\hline
\end{tabular}




\section{KÖLYÖK SPORTOLÓ PROGRAM ÖSSZEHASONLÍTÓ ÉRTÉKELÉS}

A felmérés eredményeit összehasonlító részben, egy táblázatban foglaljuk az elözetes és utólagos felmérésben kapott adatokat, így állapíthatjuk meg a fejlődés mértékét.

Dátum: Gyerek neve: Gyerek ko-

ra:

Hány hétig vett részt a gyerek a Kölyök Sportoló Programban?

Hasonlítsuk össze a gyerek hozzáállását/hangulatát az előzetes és az utólagos felmérések alatt! A keretben jegyezzünk fel minden olyan tényezőt, ami befolyásolhatta a gyerek képességét/lehetőségét, hogy a gyerek a képességeihez képest a legjobb teljesítményt nyújtsa.

Az előzetes és az utólagos felmérések alapján mely készségeit tudja a gyerek továbbfejleszteni a későbbi Kölyök sportoló foglalkozásokon és otthon?

\begin{tabular}{|c|c|c|c|c|c|c|c|}
\hline \multirow{3}{*}{$\begin{array}{l} \\
\\
\end{array}$} & \multicolumn{2}{|c|}{ Eljárás/Feladat } & \multicolumn{2}{|c|}{ Előzetes felmérés } & \multicolumn{2}{|c|}{$\begin{array}{l}\text { Utólagos felmé- } \\
\text { rés }\end{array}$} & Válto- \\
\hline & $\begin{array}{c}1 . \\
\text { Állás egy }\end{array}$ & $\begin{array}{l}\text { Hány másod- } \\
\text { percig tudott a } \\
\text { gyerek jobb } \\
\text { lábon állni? }\end{array}$ & mp & $\underset{\text { N/A }}{\square}$ & - $\mathrm{mp}$ & $\begin{array}{r}\square \\
\mathrm{N} / \mathrm{A}\end{array}$ & \\
\hline & & $\begin{array}{l}\text { Hány másod- } \\
\text { percig tudott a } \\
\text { gyerek bal lábon } \\
\text { állni? }\end{array}$ & mp & $\begin{array}{c}\square \\
\text { N/A }\end{array}$ & $\mathrm{mp}$ & $\begin{array}{r}\square \\
\mathrm{N} / \mathrm{A}\end{array}$ & \\
\hline & $\begin{array}{l}2 . \\
\text { Állás láb- } \\
\text { ujjhegyen }\end{array}$ & $\begin{array}{l}\text { Hány másod- } \\
\text { percig tudott a } \\
\text { gyerek lábujjhe- } \\
\text { gyen állni? }\end{array}$ & mp & $\begin{array}{c}\square \\
\text { N/A }\end{array}$ & mp & $\begin{array}{c}\square \\
\text { N/A }\end{array}$ & \\
\hline
\end{tabular}




\begin{tabular}{|c|c|c|c|c|c|c|}
\hline \multirow{5}{*}{ 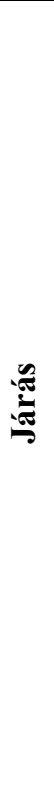 } & \multirow{2}{*}{$\begin{array}{c}1 . \\
\text { Járás } \\
\text { egyenes } \\
\text { vonalon }\end{array}$} & $\begin{array}{c}\text { Hány lábbal } \\
\text { tudott a gyerek a } \\
\text { vonalon marad- } \\
\text { ni? }\end{array}$ & $\begin{array}{l}0 \\
1 \\
2\end{array}$ & $\begin{array}{c}\square \\
\text { N/A }\end{array}$ & $\begin{array}{l}0 \\
1 \\
2\end{array}$ & $\begin{array}{c}\square \\
\text { N/A }\end{array}$ \\
\hline & & $\begin{array}{l}\text { Mekkora távol- } \\
\text { ságot tudott } 1, \\
\text { vagy } 2 \text { lábbal a } \\
\text { vonalon járni? }\end{array}$ & ${ }^{\mathrm{m}}$ & $\begin{array}{c}\square \\
\text { N/A }\end{array}$ & ${ }^{\mathrm{m}}$ & $\begin{array}{c}\square \\
\text { N/A }\end{array}$ \\
\hline & $\begin{array}{c}2 . \\
\text { Járás és } \\
\text { tárgy szál- } \\
\text { lítása } \\
\end{array}$ & $\begin{array}{l}\text { Mekkora távol- } \\
\text { ságot tudott } \\
\text { megtenni a } \\
\text { gyerek? }\end{array}$ & ${ }^{\mathrm{m}}$ & $\begin{array}{c}\square \\
\text { N/A }\end{array}$ & $\varlimsup^{\mathrm{m}}$ & $\begin{array}{c}\square \\
\text { N/A }\end{array}$ \\
\hline & $\begin{array}{c}3 . \\
\text { Lépés } \\
\text { oldalazva }\end{array}$ & $\begin{array}{l}\text { Mekkora távol- } \\
\text { ságot tudott } \\
\text { megtenni a } \\
\text { gyerek? }\end{array}$ & ${ }^{\mathrm{m}}$ & $\begin{array}{c}\square \\
\text { N/A }\end{array}$ & ${ }^{\mathrm{m}}$ & $\begin{array}{c}\square \\
\text { N/A }\end{array}$ \\
\hline & $\begin{array}{c}4 . \\
\text { Lépés } \\
\text { hátrafelé }\end{array}$ & $\begin{array}{l}\text { Mekkora távol- } \\
\text { ságot tudott } \\
\text { megtenni a } \\
\text { gyerek? }\end{array}$ & ${ }^{\mathrm{m}}$ & $\begin{array}{c}\square \\
\text { N/A }\end{array}$ & m & $\begin{array}{c}\square \\
\text { N/A }\end{array}$ \\
\hline \multirow{5}{*}{ 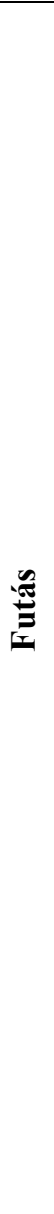 } & \multirow[b]{3}{*}{$\begin{array}{l}1 . \\
\text { Futómoz- } \\
\text { gás }\end{array}$} & $\begin{array}{l}\text { Tud a gyerek } \\
\text { futni? } \\
\text { (megfelelö vá- } \\
\text { lasz bejelölendő) }\end{array}$ & $\begin{array}{l}\square \text { Igen } \\
\square \text { Nem }\end{array}$ & $\begin{array}{c}\square \\
\text { N/A }\end{array}$ & $\begin{array}{l}\square \text { Igen } \\
\square \text { Nem }\end{array}$ & $\begin{array}{c}\square \\
\text { N/A }\end{array}$ \\
\hline & & $\begin{array}{l}\text { A gyerek teletal- } \\
\text { pon vagy a talp- } \\
\text { párnáin terhel? } \\
\text { (megfelelö vá- } \\
\text { lasz bejelölendö) }\end{array}$ & $\begin{array}{l}\square \text { teletal- } \\
\text { pon } \\
\square \text { talppár- } \\
\text { náin }\end{array}$ & $\begin{array}{c}\square \\
\text { N/A }\end{array}$ & $\begin{array}{l}\square \text { tele- } \\
\text { talpon } \\
\square \text { talp- } \\
\text { párnáin }\end{array}$ & $\begin{array}{c}\square \\
\text { N/A }\end{array}$ \\
\hline & & $\begin{array}{l}\text { Hol vannak a } \\
\text { gyerek karjai } \\
\text { futáskor? }\end{array}$ & $\begin{array}{c}\square \\
\text { a test mel- } \\
\text { lett } \\
\square \\
\text { a test elött } \\
\square \\
\text { előre-hátra } \\
\text { mozognak }\end{array}$ & $\begin{array}{c}\square \\
\text { N/A }\end{array}$ & $\begin{array}{c}\square \\
\text { a test } \\
\text { mellett } \\
\square \\
\text { a test } \\
\text { elött } \\
\square \\
\text { elöre- } \\
\text { hátra } \\
\text { mozog- } \\
\text { nak }\end{array}$ & $\begin{array}{c}\square \\
\text { N/A }\end{array}$ \\
\hline & $\begin{array}{l}2 . \\
\text { Futás se- } \\
\text { bessége } \\
\text { rövid tá- } \\
\text { von }\end{array}$ & $\begin{array}{l}\text { Hány másod- } \\
\text { percbe került az } \\
5 \text { méter lefutá- } \\
\text { sa? }\end{array}$ & mp & $\begin{array}{c}\square \\
\text { N/A }\end{array}$ & mp & $\begin{array}{c}\square \\
\text { N/A }\end{array}$ \\
\hline & $\begin{array}{l}3 . \\
\text { Futás se- } \\
\text { bessége } \\
\text { hosszú } \\
\text { távon }\end{array}$ & $\begin{array}{l}\text { Hány másod- } \\
\text { percbe került a } \\
10 \text { méter lefutá- } \\
\text { sa? }\end{array}$ & $\mathrm{mp}$ & $\begin{array}{c}\square \\
\text { N/A }\end{array}$ & mp & $\begin{array}{c}\square \\
\text { N/A }\end{array}$ \\
\hline
\end{tabular}




\begin{tabular}{|c|c|c|c|c|c|c|}
\hline \multirow{6}{*}{ 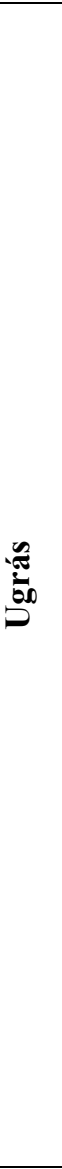 } & $\begin{array}{l}1 . \\
\text { Leug- } \\
\text { rás }\end{array}$ & $\begin{array}{l}\text { Tudott páros } \\
\text { lábra érkezni? }\end{array}$ & $\begin{array}{l}\square \text { Igen } \\
\square \text { Nem }\end{array}$ & $\begin{array}{c}\square \\
\text { N/A }\end{array}$ & $\begin{array}{l}\square \text { Igen } \\
\square \text { Nem }\end{array}$ & $\begin{array}{c}\square \\
\text { N/A }\end{array}$ \\
\hline & \multirow{2}{*}{$\begin{array}{l}2 . \\
\text { Elöre } \\
\text { ugrás }\end{array}$} & $\begin{array}{l}\text { Mekkorát tudott } \\
\text { ugrani a gyerek? }\end{array}$ & $\mathrm{cm}^{\mathrm{cm}}$ & $\begin{array}{c}\square \\
\text { N/A }\end{array}$ & $\mathrm{cm}^{\mathrm{cm}}$ & $\begin{array}{c}\square \\
\text { N/A }\end{array}$ \\
\hline & & $\begin{array}{l}\text { Páros lábbal } \\
\text { elrugaszkodva } \\
\text { és páros lábra } \\
\text { érkezve ugrott a } \\
\text { gyerek? }\end{array}$ & $\begin{array}{l}\square \text { Igen } \\
\square \text { Nem }\end{array}$ & $\begin{array}{c}\square \\
\text { N/A }\end{array}$ & $\begin{array}{l}\square \text { Igen } \\
\square \text { Nem }\end{array}$ & $\begin{array}{c}\square \\
\text { N/A }\end{array}$ \\
\hline & \multirow[b]{2}{*}{$\begin{array}{c}3 . \\
\text { Magas } \\
\text { ugrás }\end{array}$} & $\begin{array}{l}\text { Mekkorát tudott } \\
\text { ugrani a gyerek? }\end{array}$ & $\mathrm{cm}$ & $\begin{array}{c}\square \\
\text { N/A }\end{array}$ & $\mathrm{cm}^{\mathrm{cm}}$ & $\begin{array}{c}\square \\
\mathrm{N} / \mathrm{A}\end{array}$ \\
\hline & & $\begin{array}{l}\text { Páros lábbal } \\
\text { elrugaszkodva } \\
\text { és páros lábra } \\
\text { érkezve ugrott a } \\
\text { gyerek? }\end{array}$ & $\begin{array}{l}\square \text { Igen } \\
\square \text { Nem }\end{array}$ & $\begin{array}{c}\square \\
\text { N/A }\end{array}$ & $\begin{array}{l}\square \text { Igen } \\
\square \text { Nem }\end{array}$ & $\begin{array}{c}\square \\
\text { N/A }\end{array}$ \\
\hline & $\begin{array}{c}4 . \\
\text { Egy lábon } \\
\text { ugrálás }\end{array}$ & $\begin{array}{l}\text { Hányat tudott } \\
\text { ugrani a gyerek? }\end{array}$ & $\ldots$ ugrás & $\begin{array}{c}\square \\
\text { N/A }\end{array}$ & $\overline{\text { ugrás }}$ & $\begin{array}{c}\square \\
\text { N/A }\end{array}$ \\
\hline \multirow[b]{3}{*}{ 㷎 } & $\begin{array}{l}1 . \\
\text { Labda } \\
\text { gurítás }\end{array}$ & $\begin{array}{l}\text { Vissza tudta } \\
\text { gurítani a gye- } \\
\text { rek a labdát? }\end{array}$ & $\begin{array}{l}\square \text { Igen } \\
\square \text { Nem }\end{array}$ & $\begin{array}{c}\square \\
\text { N/A }\end{array}$ & $\begin{array}{l}\square \text { Igen } \\
\square \text { Nem }\end{array}$ & $\begin{array}{c}\square \\
\text { N/A }\end{array}$ \\
\hline & $\begin{array}{c}2 . \\
\text { Kendő } \\
\text { felemelése }\end{array}$ & $\begin{array}{l}\text { Hogyan vette fel } \\
\text { a gyerek a ken- } \\
\text { dőt? }\end{array}$ & $\begin{array}{c}\square \\
\text { ujjakkal és } \\
\text { tenyérrel } \\
\square \\
3 \text { vagy } \\
\text { több ujjal } \\
\square \\
2 \text { ujjbegy- } \\
\text { gyel }\end{array}$ & $\begin{array}{c}\square \\
\text { N/A }\end{array}$ & $\begin{array}{c} \\
\text { ujjakkal } \\
\text { és te- } \\
\text { nyérrel } \\
\square \\
3 \text { vagy } \\
\text { több ujjal } \\
\square \\
2 \text { ujj- } \\
\text { beggyel } \\
\end{array}$ & $\begin{array}{c}\square \\
\text { N/A }\end{array}$ \\
\hline & $\begin{array}{c}3 . \\
\text { Labda } \\
\text { elkapása }\end{array}$ & $\begin{array}{c}\text { Nyújtotta a } \\
\text { gyerek a kezét, } \\
\text { hogy elkapja a } \\
\text { labdát? }\end{array}$ & $\begin{array}{l}\square \text { Igen } \\
\square \text { Nem }\end{array}$ & $\begin{array}{c}\square \\
\mathrm{N} / \mathrm{A}\end{array}$ & $\begin{array}{l}\square \text { Igen } \\
\square \text { Nem }\end{array}$ & $\begin{array}{c}\square \\
\mathrm{N} / \mathrm{A}\end{array}$ \\
\hline
\end{tabular}




\begin{tabular}{|c|c|c|c|c|c|}
\hline & $\begin{array}{l}\text { Sikerült elkap- } \\
\text { nia a labdát? }\end{array}$ & $\begin{array}{l}\square \text { Igen } \\
\square \text { Nem }\end{array}$ & $\begin{array}{l}\square \\
\mathrm{N} / \mathrm{A}\end{array}$ & $\begin{array}{l}\square \text { Igen } \\
\square \text { Nem }\end{array}$ & $\begin{array}{l}\square \\
\text { N/A }\end{array}$ \\
\hline $\begin{array}{c}4 . \\
\text { Alsó egy- } \\
\text { kezes } \\
\text { dobás }\end{array}$ & $\begin{array}{l}\text { Milyen messzire } \\
\text { tudta dobni a } \\
\text { gyerek a labdát? }\end{array}$ & $\overline{\text { méter }}$ & $\begin{array}{c}\square \\
\text { N/A }\end{array}$ & $\overline{\text { méter }}$ & $\begin{array}{c}\square \\
\text { N/A }\end{array}$ \\
\hline $\begin{array}{c}5 . \\
\text { Felső egy- } \\
\text { kezes } \\
\text { dobás }\end{array}$ & $\begin{array}{l}\text { Milyen messzire } \\
\text { tudta dobni a } \\
\text { gyerek a labdát? }\end{array}$ & méter & $\begin{array}{c}\square \\
\mathrm{N} / \mathrm{A}\end{array}$ & $\overline{\text { méter }}$ & $\begin{array}{l}\square \\
\mathrm{N} / \mathrm{A}\end{array}$ \\
\hline $\begin{array}{c}6 . \\
\text { Labda } \\
\text { rúgása }\end{array}$ & $\begin{array}{l}\text { Milyen messzire } \\
\text { tudta rúgni a } \\
\text { gyerek a labdát? }\end{array}$ & méter & $\begin{array}{c}\square \\
\text { N/A }\end{array}$ & méter & $\begin{array}{l}\square \\
\text { N/A }\end{array}$ \\
\hline $\begin{array}{c}7 . \\
\text { Guruló } \\
\text { labda rú- } \\
\text { gása }\end{array}$ & $\begin{array}{l}\text { Milyen messzire } \\
\text { tudta rúgni a } \\
\text { gyerek a labdát? }\end{array}$ & $\overline{\text { méter }}$ & $\begin{array}{l}\square \\
\mathrm{N} / \mathrm{A}\end{array}$ & $\overline{\text { méter }}$ & $\begin{array}{l}\square \\
\mathrm{N} / \mathrm{A}\end{array}$ \\
\hline
\end{tabular}

Eredeti nyelven: Special Olympics Young Athletes Motor Skills Assessment Check list

Kiadta: Magyar Speciális Olimpia Szövetség

Fordította: Jakabacska Tibor

Lektorálta: A hazai Kölyök Sportoló edzők 